\title{
LOS MATRIMONIOS EN FORMA RELIGIOSA NO CANÓNICA: CELEBRACIÓN E INSCRIPCIÓN EN EL REGISTRO CIVIL DE ACUERDO CON LAS REFORMAS OPERADAS POR LA LEY 15/2015, DE 2 DE JULIO, DE LA JURISDICCIÓN VOLUNTARIA
}

\author{
Marriages in non-Catholic Religious Form: Celebration and \\ Registration in the Civil Registry According to the Reforms Carried \\ Out by the Voluntary Jurisdiction Act 15/2015 of 2nd July
}

\author{
M. ${ }^{a}$ CRISTINA BERENGUER ALBALADEJO \\ Profesora Ayudante Doctora de Derecho Civil \\ Universidad de Alicante
}

\author{
Recepción: 06/07/2015 \\ Aceptación después de revisión: 30/07/2015 \\ Publicación: 27/11/2015
}

I. FORMAS MATRIMONIALES RELIGIOSAS CON EFICACIA CIVIL EN NUESTRO PAíS: 1. Estado de la cuestión hasta el momento presente. 2. Modificaciones operadas en esta materia por la Ley 15/2015, de 2 de julio, de la Jurisdicción Voluntaria. II. EL EXPEDIENTE DE CAPACIDAD MATRIMONIAL EN LOS MATRIMONIOS RELIGIOSOS ACATÓLICOS: 1 . Su regulación en los Acuerdos de 1992 y en la Instrucción de la Dirección General de Registros y del Notariado, de 10 de febrero de 1993. 2. Situación jurídica del matrimonio celebrado sin tramitar expediente previo o caducado el certificado de capacidad matrimonial: a) Matrimonios en forma evangélica y judía. b) Matrimonios en forma islámica. c) Consideraciones sobre la cuestión a tenor de las modificaciones operadas por la LJV. III. LA INSCRIPCIÓN DEL MATRIMONIO RELIGIOSO ACATÓLICO EN EL REGISTRO CIVIL: PARTICULAR REFERENCIA AL MATRIMONIO ISLÁMICO. 1. Título de inscripción, calificación y procedimiento registral. 2. Problemática de los matrimonios cuya inscripción se ha denegado: el caso de la sentencia del Tribunal Constitucional 194/2014, de 1 de diciembre. IV. BREVE EXPOSICIÓN DE LAS MODIFICACIONES LEGISLATIVAS OPERADAS POR LA LEY 15/2015, DE 2 DE JULIO, DE LA JURISDICCIÓN VOLUNTARIA RESPECTO A LA TRAMTTACIÓN DEL EXPEDIENTE MATRIMONIAL. BIBLIOGRAFIAA.

\section{RESUMEN}

La institución matrimonial ha sufrido numerosas e importantes modificaciones operadas por la Ley 15/2015, de 2 de julio, de la Jurisdicción Voluntaria. Este trabajo se centrará en analizar aquellas que afectan a los matrimonios en forma religiosa. En concreto, la ampliación de las formas de celebración con eficacia civil en España y los cambios en la regulación de las formas matrimoniales religiosas ya 
reconocidas. Esto se hará mediante un estudio comparativo entre la situación hasta ahora vigente y la que resultará de la entrada en vigor de la norma citada.

PALABRAS CLAVE: Matrimonio en forma religiosa; formas de matrimonio; expediente de capacidad matrimonial; matrimonio no inscrito; prueba del matrimonio; pensión de viudedad; matrimonio islámico; Ley de la Jurisdicción Voluntaria.

\section{ABSTRACT}

The institution of marriage has been recently amended by the Voluntary Jurisdiction Act 15/2015. This paper will focus on analysing the changes related to the religious form of the civil marriage. In particular, the expansion of religious forms of marriage with civil efficacy in Spain and the changes in the regulation of marriages already recognized. This will be done through a comparative study of the current situation and that will result when come into force the mentioned regulation.

KEY WORDS: Religious forms of marriage; celebration of marriage; marriage license; unregistered marriage; marriage evidence; widow's pension; islamic marriage; Voluntary Jurisdiction Act.

\section{FORMAS MATRIMONIALES RELIGIOSAS CON EFICACIA CIVIL EN NUESTRO PAÍS}

\section{Estado de la cuestión hasta el momento presente}

El artículo 49 CC refleja el criterio adoptado por nuestro legislador en cuanto a las formas de celebración del matrimonio civilmente eficaces. Así, reconoce efectos civiles a los matrimonios celebrados ante el juez, alcalde o funcionario señalado por el Código - matrimonios en forma civil-, y a los celebrados en la forma religiosa legalmente prevista - matrimonios en forma religiosa $-{ }^{\prime}$. Respecto a estos últimos, concreta el artículo 59 CC que las formas religiosas que podrán alcanzar eficacia civil serán las previstas por las confesiones religiosas ins-

${ }^{1}$ Este precepto, así como otros muchos relativos al matrimonio, han sido recientemente modificados por la Ley 15/2015, de 2 de julio, de la Jurisdicción Voluntaria. Por lo que se refiere en concreto al artículo 49 CC, el único cambio operado es que donde antes decía que el matrimonio se podía contraer «ante el juez, alcalde o funcionario señalado por este Código», ahora se dice que el matrimonio podrá contraerse «en la forma regulada por este Código», para dar cabida al matrimonio celebrado ante personas distintas a las enunciadas. Dejaremos simplemente apuntada esta cuestión porque será objeto de tratamiento más adelante. 
critas en el Registro de Entidades Religiosas, «en los términos acordados con el Estado o, en su defecto, autorizados por la legislación de este». Por tanto, previa adquisición de personalidad jurídica por la confesión - mediante la correspondiente inscripción-, esta puede ver reconocidos sus ritos matrimoniales por una doble vía: mediante la firma de un acuerdo o convenio con el Estado español a través del cual se le reconozca eficacia jurídica; o a través de la autorización del propio Estado mediante una ley unilateral, sin necesidad de acuerdo.

Hasta ahora, la vía del acuerdo ha sido la única empleada para otorgar dicho reconocimiento. El Estado ha firmado cuatro acuerdos con confesiones religiosas: en primer lugar, e incluso antes de la reforma del Código Civil de 1981, se firmó el Acuerdo sobre Asuntos Jurídicos con la Santa Sede el 3 de enero de 1979, cuyo artículo 6 reconoce eficacia civil al matrimonio contraído según las normas del Derecho canónico; posteriormente, y aunque hubo que esperar más de una década desde la citada reforma para que el legislador desarrollara los artículos 49.2 y 59 CC, se suscribieron los Acuerdos de Cooperación del Estado con la Federación de Entidades Religiosas Evangélicas de España (FEREDE), la Federación de Comunidades Israelitas de España (FCI) y la Comisión Islámica de España (CIE) - en adelante, los Acuerdos-, que fueron aprobados respectivamente por las Leyes 24/1992, 25/1992 y 26/1992, de 10 de noviembre, en cuyos artículos 7 se consagra la eficacia civil del matrimonio celebrado según sus ritos religiosos ${ }^{2}$.

El reconocimiento de efectos a los matrimonios de las confesiones mencionadas solo se predica respecto de la forma de celebración matrimonial o de exteriorización del consentimiento matrimonial, y no respecto a las normas confesionales sustantivas ${ }^{3}$. Ello implica que para que

2 Sobre la génesis de tales Acuerdos puede verse con más detalle, NAvARRO-VALLS, R., La eficacia civil del matrimonio de las minorías religiosas en el Derecho español, 1993, o FERNÁNDEZ-CORONADO GONZÁLEZ, A., "Los acuerdos con confesiones minoritarias desde una perspectiva histórica. "Iter" de las negociaciones» en Acuerdos del Estado Español con Confesiones Religiosas Minoritarias, coord., V. Reina/Félix Ballesta, M.A., Madrid, 1996, pp. 131-154.

${ }^{3}$ Esta afirmación ha sido discutida respecto al matrimonio en forma canónica. No es momento de ahondar en esta cuestión a pesar de su notable incidencia en el sistema matrimonial español. Simplemente diremos que un sector doctrinal mantuvo que respecto a este matrimonio se recibía civilmente el Derecho sustantivo de la confesión católica y no solo su forma de celebración. Vid., DíEz DEL CORRAL Rivas, J., «Comentario a los artículos 69 y siguientes de la LRC», en Comentarios al Código Civil y Compilaciones Forales, tomo IV, vol. 3, p. 786 o GARCía CANTERO, G., «Comentario a los artículos 61 a $65 \mathrm{CC}$, Comentarios al Código Civil y Compilaciones Forales, dir., M. Albaladejo/S. Díaz Alabart, tomo II, Madrid, 1982, p. 163. Pero en sentido 
un matrimonio celebrado en forma canónica, evangélica, judía o islámica pueda alcanzar efectos en nuestro país, se deben cumplir los requisitos de capacidad y consentimiento establecidos en la legislación civil.

Además, por lo que se refiere a los matrimonios de las confesiones acatólicas, el reenvío que el artículo 7 de los Acuerdos hace a sus normativas propias a los efectos de regular la forma de celebración matrimonial, carece en realidad de trascendencia jurídica desde el momento en que el Estado establece otros requisitos formales sin los cuales estos matrimonios no desplegarán efectos: la tramitación de un expediente matrimonial previo, la intervención de un ministro religioso debidamente legitimado que autorice las nupcias y la participación de dos testigos mayores de edad $^{4}$. En base a esto, no puede decirse que se esté reconociendo la forma ritual religiosa de estas confesiones, sino que se está reconociendo una forma religiosa «pactada», que no viene a ser más que la traslación de la forma civil al ámbito religioso, en la que el ministro de culto hace las veces del juez o del funcionario civil que asiste el enlace junto con los testigos mayores de edad y certifica su celebración ${ }^{5}$. Solo el respeto de los requisitos acordados conllevará la eficacia civil del matrimonio.

contrario existe una opinión muy difundida que consideramos más acertada, vid., por todos, Martinell, J.M/Areces Piñol, M.T., «En torno a la incidencia civil de los matrimonios confesionales», en Estudios en Homenaje al profesor Martínez Valls, vol. II, Alicante, 2000, p. 915 , nota 8. Estudia este tema ampliamente NAVARRo-VALLS, R., El matrimonio religioso ante el Derecho español, Madrid, 1984, pp. 105 y ss.

${ }^{4}$ Precisamente por la exigencia de tales requisitos la doctrina considera que la remisión a la normativa ritual de cada confesión no es plena y no se admiten las formas privadas de celebración del matrimonio que en su caso puedan existir, como ocurre, por ejemplo, en el Derecho islámico. Así, entre otros, GALlego DomínguEZ, I/GALÁN SOLDEVILLA, L., «El matrimonio religioso no canónico celebrado en España, aproximación a la Leyes n. ${ }^{\circ} 24,25$ y 26 de 10 de noviembre de 1992», AC, n. ${ }^{\circ} 1,1993$, p. 233, Martinell, J.M/Areces PiÑol, M.T., op. cit., p. 923, nota 17, y LóPEZ AlarcóN, M., «El certificado de capacidad matrimonial», $A D E E$, n. ${ }^{\circ} 8,1992$, p. 187.

${ }^{5}$ El evidente paralelismo entre la forma de prestación del consentimiento matrimonial pactada en los Acuerdos y la forma civil de celebración lo pone de manifiesto la doctrina mayoritaria. Entre otros muchos, GALLEGo DomínGUEZ, I./GALÁN SOLDEVILLA, L., op. cit., p. 229, AldANONDO SALAVERRÍA, I., «Matrimonio de otras confesiones religiosas», en Derecho de Familia, coord. G. Díez-Picazo Giménez/L. Díez-Picazo y Ponce de León, Madrid, 2012, p. 399, ALENDA SALINAS, M., «El matrimonio religioso en los acuerdos del Estado español, con judíos, protestantes y musulmanes», Revista general de derecho, n. ${ }^{\circ} 600,1994$, p. 9193 , o CARRIÓN Olmos, S., «Sistema matrimonial y Acuerdos con otras confesiones», $A C$, n. $^{\circ} 1,1993$, p. 100. Para Rodríguez CHACón, R., «Autonomía de la voluntad en la eficacia civil del matrimonio celebrado según los Acuerdos españoles con las confesiones religiosas minoritarias», en Acuerdos del Estado Español con Confesiones Religiosas Minoritarias, coord., V. Reina/Félix Ballesta, M.A., Madrid, 1996, p. 708, utilizar las locuciones «matrimonio religioso no católico» o, sencillamente, 
Lo que esto implica a efectos prácticos es que la inobservancia de alguna de las normas confesionales sobre la forma de contraer, no impedirá que un matrimonio llegue a desplegar efectos civiles en nuestro país si, presupuesta la concurrencia de los requisitos de fondo en los contrayentes, se respeta la forma mínima establecida por el Estado ${ }^{6}$. Por el contrario, los matrimonios en los se cumplan escrupulosamente los requisitos formales religiosos, pero se desatiendan los civiles, tendrán efectos exclusivamente en el ámbito intraconfesional o de conciencia de los contrayentes, pero no para el Estado 7 .

\section{Modificaciones operadas en esta materia por la Ley 15/2015, de 2 de julio, de la Jurisdicción Voluntaria}

\section{El 18 de junio de 2015 se aprobó por el Pleno del Congreso la Ley} de la Jurisdicción Voluntaria (en adelante, LJV) ${ }^{8}$. Dicha norma supone

«matrimonio religioso» para referirse a las modalidades matrimoniales reguladas en el artículo 7 de los Acuerdos es inexacto desde el punto de vista técnico, siendo más exacto hablar de «formas de matrimonio civil con posibilidad de ritos religiosos simultáneos».

${ }^{6}$ Por ello, autores como Alenda Salinas, M., op. cit., p. 9205, se preguntan, con buen criterio, qué papel juega la normativa formal religiosa, teniendo en cuenta que llenar la forma establecida por el Estado es requisito indispensable para la validez civil del matrimonio. Para López ALARCón, M., op. cit., p. 190, la forma religiosa y sus defectos no tiene relevancia civil, lo que resulta incongruente con su condición de matrimonio civil con forma religiosa. LuCEs GiL, F., Derecho del Registro Civil, Barcelona, 2002, p. 232, nota 17 , poniendo como ejemplo el matrimonio judío señala que la celebración del mismo se compone de un doble ritual: el de los esponsales y el de la celebración propiamente dicha precedida de la lectura del contrato matrimonial, pero para la validez civil del mismo basta con la prestación del consentimiento a presencia del rabino y dos testigos. No obstante, esta postura no es compartida de forma unánime por la doctrina, sino que para algunos autores si no se cumplen también los requisitos formales de la confesión, el matrimonio no podría gozar de efectos civiles aun cuando se hubiese respetado la forma estipulada en los Acuerdos. Vid., en esta línea, por todos, FERNÁNDEZ CORONADO, A., «Los Acuerdos del Estado español con la Federación de Entidades Religiosas Evangélicas de España (FEREDE) y de Comunidades Israelitas (FCI)», ADEE, vol. VII, 1991, p. 557.

7 Ello en virtud del artículo 2 LOLR que, en desarrollo del principio constitucional de libertad religiosa, establece la libertad para celebrar ritos matrimoniales. En este sentido, por ejemplo, al Estado no le bastaría con el ceremonial religioso según el Derecho islámico para otorgar eficacia al matrimonio, puesto que las exigencias de validez del mismo son menores que las civiles al no requerirse que los testigos sean mayores de edad, al ser posible consentir ante dos adules (figura semejante al notario) pero sin más testigos, al posibilitar que la mujer virgen no consienta expresamente y que, aun estando presente, sea su tutor representante quien lo emita por ella, etc.

${ }^{8} \mathrm{BOE} \mathrm{n.}^{\circ} 158,3$ de julio de 2015, Sec. I, pp. 54068 y ss. 
una reforma importante del Derecho matrimonial al modificar numerosos preceptos del Código Civil y de la todavía no vigente Ley 20/2011, de 21 de julio, del Registro Civil, modificaciones que implican los correspondientes ajustes en las Leyes 24, 25 y 26 de 1992 anteriormente mencionadas 9 . A pesar del interés que suscitan todos estos cambios, su análisis excede con mucho de los límites que debe respetar el presente trabajo. Por ello, nos centraremos únicamente en las novedades que afectan a las formas y formalidades para la celebración de matrimonios en forma religiosa distinta a la canónica, extremo que suscita interesantes cuestiones que iremos analizando a lo largo de estas páginas, sin perjuicio de que se hagan las referencias oportunas a otras importantes reformas operadas por la LJV en este ámbito.

Por lo que ahora interesa, dicha norma amplía las formas matrimoniales religiosas que podrán gozar de eficacia civil en nuestro país. Y lo hace mediante la vía de la autorización legislativa del Estado (art. 59 $\mathrm{CC}$ ), mecanismo de reconocimiento de efectos civiles que desde su habilitación por el legislador en 1981 no había siḍo utilizado. Por tanto, se abre la posibilidad de que los ritos matrimoniales de determinadas iglesias, confesiones, comunidades religiosas o federaciones de las mismas puedan gozar de efectos en nuestro país, sin necesidad de un previo Acuerdo con el Estado.

Es el artículo $60.2 .^{\circ} \mathrm{CC}$ el que recoge esta importante modificación. Según dispone este nuevo precepto, las iglesias, confesiones, comunidades religiosas o federaciones de las mismas que pueden llegar a ver reconocidos sus ritos matrimoniales, son únicamente aquellas que, estando inscritas en el Registro de Entidades Religiosas, cuenten además con el reconocimiento administrativo de notorio arraigo en España ${ }^{10}$. Nótese que hasta ahora ambos requisitos solo abrían la puerta a un po-

${ }^{9}$ Según ordena el último apartado del artículo 7 de los Acuerdos, «las normas de este artículo relativas al procedimiento para hacer efectivo el derecho que en el mismo se establece, se ajustarán a las modificaciones que en el futuro se produzcan en la legislación del Registro Civil», previa audiencia de la FEREDE, FCI y CIE. No obstante, en la Memoria del Análisis de Impacto Normativo del Anteproyecto de la Ley de la Jurisdicción Voluntaria, de 25 de julio de 2014, no se contiene la menor referencia a la necesidad de dar audiencia a estos tres entes o federaciones de entidades religiosas.

${ }^{10}$ Actualmente, la Iglesia de Jesucristo de los Santos de los Últimos Días (mormones) logró el notorio arraigo en 2003; los Testigos Cristianos de Jehová, en 2006; la Federación de Entidades Budistas de España, en 2007; y, por último, la Iglesia Ortodoxa, en 2010. Tal como expone la Memoria del Análisis de Impacto Normativo del Anteproyecto de Ley de la Jurisdicción Voluntaria, de 25 de julio de 2014, p. 61, «el colectivo de personas que potencialmente pueden verse afectadas por la reforma, aún sin cifras exactas, se han estimado del modo siguiente: entre 100 y 120 mil Testigos de 
sible pacto con el Estado en virtud del artículo 7 de la LOLR, pero en ningún caso garantizaban que este aceptara su firma ${ }^{11}$. El único derecho que se reconocía a una confesión con notorio arraigo era el de participar en la Comisión Asesora de Libertad Religiosa ex artículo 8 LOLR. Pero salvo esto, tal reconocimiento carecía de consecuencias legales ${ }^{12}$. Sin embargo, tras la modificación del artículo $60 \mathrm{CC}$, despliega una consecuencia jurídica importante para las confesiones inscritas: la eficacia civil de sus ritos matrimoniales. Por tanto, el cambio producido respecto a la utilidad o efectos de este reconocimiento no es cuestión baladí.

Esta ampliación de las formas religiosas civilmente eficaces nos suscita varias cuestiones: en primer lugar, nos preguntamos qué razones han llevado al legislador a optar por dicha extensión y a condicionarla al criterio del notorio arraigo; y en segundo lugar, por qué siguen siendo ritos exclusivamente de carácter religioso los que son tenidos en cuenta.

La Exposición de Motivos de la LJV justifica esta opción legislativa en atención «al pluralismo religioso existente en la sociedad española», pero no se pronuncia sobre las razones por las que limita este reconocimiento a las confesiones con notorio arraigo en nuestro país, en vez de optar por un mecanismo genérico de reconocimiento de efectos civiles a cualesquiera otras formas matrimoniales religiosas.

Como expone Polo Sabau, aunque en el trasfondo de la reforma está la necesidad de hacer realmente efectivo el principio de igualdad, cabrían otras alternativas que respetarían en mayor medida esta igualdad en el ejercicio del derecho a contraer matrimonio ${ }^{13}$. Tales alternativas irían desde la instauración de un sistema de matrimonio civil obligatorio ${ }^{14}$, hasta la articulación de un sistema común de reconocimiento de eficacia civil a

Jehová; entre 50 y 60 mil mormones; en torno a 80 mil budistas y de 800 mil ortodoxos (procedentes de Rumania, principalmente)».

1 Así lo apuntó la Audiencia Nacional en su sentencia de 29 de diciembre de 1995 en su FD 2. (LA LEY 13222\1995).

${ }_{12}$ El hecho de que tal reconocimiento no tuviera consecuencias jurídicas no significa que el mismo careciese de consecuencias sociales, ya que supone una legitimación pública del Estado a una confesión religiosa minoritaria.

${ }^{13}$ Polo SABAU, J.R., «La función de la forma de celebración del matrimonio y el principio de igualdad: algunas observaciones a la luz del proyecto de ley de la jurisdicción voluntaria» Revista de Derecho Civil, vol. II, n. ${ }^{\circ} 1$, Estudios, p. 36.

14 Este sistema es el que rige, por ejemplo, en Francia, Alemania o Bélgica y la mayoría de los países del Este de Europa y de Hispanoamérica. Un análisis de los sistemas matrimoniales en los países de la UE, puede verse en ACUÑA GUIROLA, S./Domínguez Bartolomé, R., Matrimonio religioso y Unión Europea, Granada, 2013, pp. 345 y ss. 
cualquier forma religiosa de celebración ${ }^{15}$, e incluso a uno en que también se tuvieran en cuenta consideraciones distintas a las religiosas para el reconocimiento de dicha eficacia ${ }^{16}$, debiendo cumplirse en los dos últimos casos mencionados unos requisitos mínimos de seguridad y certeza en la prestación del consentimiento matrimonial impuestos por el Estado.

En nuestra opinión, si bien el sistema de matrimonio civil obligatorio es el más neutral y el más idóneo para garantizar el principio de igualdad y no discriminación, no nos parece nada descartable la opción por la que se decanta el autor citado, esto es, la implantación de un mecanismo general que permita a cualquier ciudadano acceder a la eficacia civil de los ritos propios de su Confesión (e incluso, de su etnia), al margen del carácter más o menos mayoritario de esta última. Y ello porque el notorio arraigo es un criterio sociológico que nada tiene que ver con la existencia o no de un consentimiento válido ${ }^{17}$. Quizá un sistema de estas características tuviera más aceptación en España que el de matrimonio civil obligatorio, teniendo en cuenta que al admitir la pluralidad de formas de celebración (civil y religiosa) se aproxima en mayor medida a nuestro sistema matrimonial vigente.

${ }^{15}$ Sistema seguido en Inglaterra, aunque con matices, porque en dicho país tanto el matrimonio anglicano como el judío y el cuáquero, gozan de un tratamiento particular que se explica básicamente por razones de orden histórico, de forma similar a lo que ocurre en España con el matrimonio canónico. Sobre estas cuestiones puede verse Probert, R., Family Law in England and Wales, 2011, pp. 78 y ss. En el Derecho inglés se atiende exclusivamente a garantizar que el consensus se da entre personas civilmente capaces para ello y que es declarado con la suficiente certeza y de un modo que permita satisfacer unas mínimas exigencias de seguridad jurídica. Por ello se exige, por un lado y como requisito previo, la obtención de un certificado matrimonial expedido por el Registro Civil, y por otro lado, que en el desarrollo de la ceremonia se observen unos requerimientos de publicidad del acto - presencia de testigos y obligación de llevarlo a cabo públicamente 0 «de puertas abiertas»- y se cumpla una específica fórmula declarativa por parte de los contrayentes que inequívocamente implique la manifestación consciente y deliberada de su recíproca voluntad conyugal. Vid., sección 44 de la Marriage Act 1949. Puede consultarse también AcuÑa GUIROLA, S./DoMíNGUEZ BARTOLOMÉ, R., op. cit., pp. 378-380.

${ }^{16}$ En Escocia, por ejemplo, el debate acerca del reconocimiento de eficacia a las formas matrimoniales propias de grupos sociales ideológicos o filosóficos de naturaleza no religiosa para conseguir una mayor realización del principio de igualdad, ha dado lugar a la reciente creación legislativa de una nueva modalidad de matrimonio civilmente válido denominado matrimonio de creencia (belief marriage). Así lo explica Polo SABAU, J.R., op. cit., p. 49.

17 Sobre la importancia que históricamente ha ostentado el consentimiento como elemento esencial y verdaderamente constitutivo del matrimonio y la evolución legislativa conducente a la esencialización de la forma, habla Polo SABAU, J.R., op. cit., pp. 29 y 30 , citando doctrina relevante sobre el tema. 
Sin perjuicio de que las alternativas propuestas por la doctrina sean dignas de consideración, no podemos ignorar que nuestro legislador ha optado por establecer el criterio del notorio arraigo de las confesiones religiosas como condición para el reconocimiento de sus ritos matrimoniales. Siendo esto así, creemos que los esfuerzos más inmediatos tendrían que ir dirigidos a normativizar este concepto puesto que su indefinición actual contribuye a que la Administración goce de un margen de discrecionalidad excesivamente amplio a la hora de otorgarlo ${ }^{18}$. En este sentido, el Ministerio de Justicia, a través de la Subdirección General de Relaciones con las Confesiones, está trabajando para aprobar un Real Decreto que fije el procedimiento y las garantías para llevarlo a $\mathrm{cabo}^{19}$. La aprobación de una norma de este tipo sería más que conveniente desde el momento en que nuestro legislador ha decidido otorgar consecuencias jurídicas relevantes a este reconocimiento administrativo (en concreto, y de momento, la posibilidad de celebrar sus ritos matrimoniales $)^{20}$.

Por otro lado, vuelven a ser consideraciones exclusivamente de carácter religioso las que prevalecen para el reconocimiento de eficacia civil a los ritos matrimoniales, lo que a nuestro modo de ver tiene cada vez menor sentido teniendo en cuenta, por un lado, la secularización de las sociedades occidentales y, por otro, la sensibilización de la sociedad en valores como los contemplados en el artículo $14 \mathrm{CE}$ sobre igualdad y no discriminación.

Aunque no es momento de ahondar sobre la razón de que los ciudadanos tengan derecho a celebrar los ritos matrimoniales propios de su Confesión pero no, por ejemplo, los de la etnia a la que pertenecen,

18 En Portugal, además de incorporar en la Ley 16/2001, de 22 de junio, de Libertad Religiosa, el notorio arraigo (declaración de radicação), se precisó su concepto. En el artículo 37 se enumeran una serie de elementos que deben entenderse comprendidos dentro de esta noción, incluyendo la existencia de un número de creyentes, la historia y una cierta estabilidad, y una presencia social organizada mínima en Portugal de 30 años antes de la solicitud de reconocimiento o bien la acreditación de una presencia en el extranjero de al menos 60 años.

19 Sobre el mismo puede consultarse la Memoria de actividades de la Subdirección General de Relaciones con las Confesiones en el periodo 2013-2014 (actualizada a 15 de enero de 2015).

${ }^{20}$ El legislador portugués atribuye ciertas ventajas a las confesiones que han obtenido la declaración de radicação. Entre ellas, beneficios fiscales o la eficacia civil de sus ritos matrimoniales. Vid., GONZÁLEZ SÁNCHEZ, M., «Las leyes de libertad religiosa española y portuguesa y su influencia en las leyes y en algunos proyectos de ley de libertad religiosa iberoamericanos», Revista General de Derecho Canónico y Derecho Eclesiástico del Estado, 32, 2013, p. 8. 
considero oportuno realizar algunas consideraciones acerca de por qué no se ha aprovechado la oportunidad para reconocer efectos civiles a los matrimonios de minorías étnicas con consabido arraigo en España, en concreto al matrimonio gitano, a pesar de que no son pocas las voces que se han alzado en favor de dicha posibilidad alegando que la etnia gitana cumple analógicamente con los requisitos que el Estado exigió a las Confesiones religiosas para establecer acuerdos de cooperación, esto es, el notorio arraigo y la personalidad jurídica ${ }^{21}$. Pero, a nuestro modo de ver, nada más lejos de la realidad.

Es evidente que si partimos de que el reconocimiento del notorio arraigo únicamente depende del ámbito geográfico (extensión territorial del colectivo) y el número de creyentes (o número de miembros, en este caso), la etnia gitana lo cumpliría sobradamente teniendo en cuenta su presencia en nuestro país desde hace más de seis siglos y sus integrantes. Ahora bien, debe precisarse que, aunque sean solo esas dos claves indeterminadas las que menciona la LOLR para interpretar en qué consiste dicho concepto, lo cierto es que la Comisión Asesora de Libertad Religiosa ha intentado concretarlo un poco más estableciendo otros elementos a tener en cuenta para entender cumplido este requisito: entre ellos, la existencia de una organización jurídica adecuada y vinculante para todas las entidades agrupadas en la misma, la realización de actividades sociales, culturales y asistenciales, la institucionalización de sus ministros de culto, o la tenencia de cierto número de iglesias locales o lugares de culto ${ }^{22}$.

En esta misma línea parece situarse el proyecto de Real Decreto anteriormente citado. Según la norma proyectada, y en desarrollo de los

${ }^{21}$ Un intento de legalizar este rito matrimonial se llevó a cabo con la Proposición de Ley de reconocimiento de efectos civiles al matrimonio gitano, presentada el 9 de junio de 2000 por el Grupo Parlamentario Socialista para su debate y votación en las Cortes de Aragón y su posterior remisión a la Mesa del Congreso de los Diputados, que fue finalmente retirada por el Pleno de las Cortes de Aragón el 25 de mayo de 2001. Vid., BOCA n. ${ }^{\circ} 60$, de 14 de junio de 2000 y n..$^{\circ} 138$, de 1 de junio de 2001, p. 6167. Entre nuestros autores se muestra a favor de este reconocimiento, por ejemplo, FÉLIX BALLESTA, M. A., «Reflexiones sobre el matrimonio gitano y su posible eficacia civil», $R J C$, vol. 102, n. ${ }^{\circ}$ 2, 2003, p. 114 o ARIAS DomíngueZ, A., «Matrimonio gitano y devengo de pensión de viudedad», Aranzadi Social, paraf. 35/2007 (Presentación), http://www.westlaw.es (BIB 2007\1233), p. 7. En contra, CABEZUelo ArENAS, A.L., «Matrimonio y parejas de hecho. ¿Es necesaria una reforma del sistema matrimonial español? A propósito de una inexistente discriminación por motivos étnicos», $R D P y C, \mathrm{n}^{\circ} 21,2007, \mathrm{p} .59$.

22 Vid., CAÑAmares, S., «Ley Orgánica de Libertad Religiosa: oportunidad y fundamento de una reforma», en Derecho canónico en tiempos de cambio, Madrid, 2011, pp. 39-41. 
requisitos exigidos por el artículo 7 de la LOLR, las confesiones deberán acreditar: en primer lugar, que gozan de una presencia estable y acreditada en el tiempo en España mediante su inscripción, con una antigüedad de 30 años, en el Registro de Entidades Religiosas (o durante un periodo inferior si acreditan su reconocimiento en algún país extranjero de 60 años de antigüedad); en segundo lugar, su presencia activa en la sociedad española y su implantación en el territorio de varias Comunidades Autónomas y un número representativo de entidades y lugares de culto inscritos en el Registro de Entidades Religiosas; en tercer lugar, que cuentan con una estructura interna y representación adecuada a su propia organización ${ }^{23}$.

A día de hoy, la comunidad gitana no reúne tales condiciones ${ }^{24}$. Ahora bien, si en el futuro lo hiciera, habría muchos menos obstáculos para reconocer eficacia a su rito matrimonial. No obstante, quedaría pendiente de resolver otra cuestión problemática: el hecho de que ciertas peculiaridades de su rito puedan ser contrarias al orden público por atentar contra valores consagrados en nuestra Constitución tales como la dignidad de la mujer o la igualdad entre los cónyuges ${ }^{25}$. Si bien es cierto que este escollo podría subsanarse de igual forma que se hizo en su día con el matrimonio islámico, también lo es que la regu-

${ }^{23}$ Requisitos muy similares a los recogidos en el artículo 37 LOLR portuguesa, anteriormente mencionados.

${ }^{24}$ Mantiene también esta opinión y la explica con más detalle, Musoles CuBEDo, M. C. «El matrimonio contraído según el rito gitano, ¿unión de hecho o forma de celebración con eficacia civil?», en Derecho de Familia y libertad de conciencia en los países de la Unión Europea y el Derecho comparado, Bilbao, 2001, pp. 658-662. En concreto por lo que se refiere a la autoridad ante la que se debería prestar el consentimiento, señala CABEZUElo ArenAs, A.L., op. cit., p. 48 que, a diferencia de lo que ocurre con las confesiones religiosas - las cuales cuentan con una organización y jerarquía de sus autoridades competentes para cuestiones relativas al matrimonio y su validez, y se tiene puntual conocimiento acerca de qué personas ostentan tales competencias-, esta jerarquía no está presente y ni siquiera puede conocerse en la comunidad gitana, ya que, en el supuesto de que se defendiese que dicha competencia correspondería al «patriarca», no es posible saber si es competente un patriarca u otro para celebrar cada enlace. Por ello, considera Musoles que en ese caso el Estado debería conocer, por seguridad jurídica, quién ostenta en cada momento la categoría de patriarca y exigirle el cumplimiento de ciertos requisitos.

${ }^{25}$ El hecho de que el rito gire en torno a la virginidad de la mujer y su demostración pública de la que se hace depender la honra de su familia, está bordeando los límites legales como reconoce Félix BALleStA, M. A., op. cit., p. 112, a pesar de abogar por su reconocimiento. Para CABezuelo ArenAs, A. L., op. cit., p. 48, esta práctica «responde más bien a parámetros calderonianos que a concepciones igualitarias arraigadas en nuestra Carta Magna». 
larización de este rito requeriría el compromiso de la comunidad gitana de someterse a los requisitos que fijase el Estado y asumir ciertas responsabilidades para las que, si bien no dudamos está preparada una pequeña parte de dicha comunidad, no creemos que sea la situación de la mayoría ${ }^{26}$.

Respecto a los requisitos fijados por el Estado a través de la nueva LJV para reconocer eficacia civil a los ritos matrimoniales de los mormones, testigos de Jehová, budistas y ortodoxos, el legislador ha vuelto a imponer, y esta vez de forma absolutamente unilateral, la necesidad de que el consentimiento se preste ante un ministro de culto debidamente acreditado y dos testigos mayores de edad. Valgan aquí las consideraciones anteriormente realizadas sobre la necesidad de cumplir este mínimo de forma para dicho reconocimiento, con independencia de que coincida o no con la propia de la confesión.

Pero es que además, como también se exigió en los Acuerdos con la FEREDE, la FCI y la CIE, la reforma supedita el reconocimiento de efectos a que los contrayentes tramiten un acta o expediente previo de capacidad matrimonial con arreglo a la normativa del Registro Civil, cuyo fin no es otro que acreditar que en ambos concurren los requisitos civiles establecidos en los artículos 44 a $48 \mathrm{CC}^{27}$.

${ }^{26}$ Aunque haciendo referencia al ámbito laboral, señala FéLıx BALLESTA, M. A., op. cit., p. 102, que el «gran obstáculo del colectivo gitano es pasar de lo informal a lo formal». En este sentido, el artículo $5.2 \mathrm{del}$ Convenio Marco para la Protección de las Minorías Nacionales, n. 157 del Consejo de Europa, hecho en Estrasburgo el 1 de febrero de 1995, establece que «las Partes se abstendrán de toda política o práctica encaminada a la asimilación contra su voluntad de personas pertenecientes a minorías nacionales y protegerán a esas personas contra toda acción destinada a dicha asimilación».

${ }^{27}$ En la mayoría de países en los que rige el sistema de matrimonio civil con admisión de formas religiosas de celebración, por ejemplo, Reino Unido, Australia, la mayoría de los Estados Unidos, y los países nórdicos, para la celebración religiosa ante el ministro de culto se exige la previa obtención de un certificado de capacidad o una licencia matrimonial expedida por autoridad civil competente. Es más, también se exige en la mayoría de países occidentales, con independencia del sistema matrimonial aplicable. Lo que varía es el rigor de dicho expediente. Así lo explica DE PABLO CONTRERAS, P., «Matrimonio civil y sistema matrimonial», en Tratado de Derecho de Familia, vol. 1, dir. por M. Yzquierdo Tolsada y M. Cuenca Casas, Navarra, 2011, pp. 458-49.

No puede pasarse por alto que con la reciente LJV se ha eliminado la dispensa matrimonial de edad, al elevarla de 14 a 16 años, de acuerdo con la propuesta realizada por los Ministerios de Justicia y de Sanidad, Servicios Sociales e Igualdad. Por tanto, a partir de ahora no será posible el matrimonio de menores de edad, salvo que estos se encuentren previamente emancipados, pues el matrimonio dejará de producir de derecho la emancipación. También se introducen cambios en la dispensa del impedimento 
Mediante la configuración de este último requisito como conditio sine qua non de eficacia civil, el legislador está reconociendo la trascendencia jurídica de esta formalidad previa, trascendencia que ya ostentaba respecto a los matrimonios evangélicos, judíos e islámicos, no solo por la finalidad que persigue, sino también por los problemas que genera su falta o la caducidad del certificado con que el mismo culmina. Todo ello, unido a las importantes modificaciones que ha sufrido la regulación de este trámite tanto por la Ley 20/2011, de 21 de julio, del Registro Civil, como por la recientemente aprobada Ley de la Jurisdicción Voluntaria, nos lleva a centrar nuestro trabajo de aquí en adelante en el análisis de esta formalidad, y en concreto, de su relevancia en la celebración del matrimonio en forma religiosa no canónica, de las diferencias en su regulación en función de la forma escogida, y de cómo esas diferencias inciden en el modo de practicar la inscripción en el Registro - especialmente en los matrimonios celebrados por el rito islámico - . Estas cuestiones han sido objeto de tratamiento en la reciente sentencia del Tribunal Constitucional 194/2014, de 1 de diciembre, cuya lectura ha motivado la realización del presente trabajo y a la que en su momento haremos referencia.

\section{EL EXPEDIENTE DE CAPACIDAD MATRIMONIAL EN LOS MATRIMONIOS RELIGIOSOS ACATÓLICOS}

\section{Su regulación en los Acuerdos de 1992 y en la Instrucción de la Dirección General de Registros y del Notariado, de 10 de febrero de 1993}

El régimen previsto en los Acuerdos respecto al expediente matrimonial modifica el establecido con carácter general en el artículo 63 CC para los matrimonios en forma religiosa al introducir la necesidad de que los contrayentes de los matrimonios celebrados por el rito evangélico, judío o islámico tuviesen que tramitar expediente civil previo para obtener un certificado acreditativo de su capacidad matrimonial ${ }^{28}$. Por

\footnotetext{
de muerte dolosa del cónyuge anterior y parentesco para contraer matrimonio del grado tercero entre colaterales (dispensables ahora por el juez de 1. Instancia). Vid., artículos 81 a 84 y DF $1{ }^{a}$ LJV.

${ }^{28}$ Téngase en cuenta que el artículo $63 \mathrm{CC}$ exonera a los matrimonios en forma religiosa de tener que tramitar expediente previo a la celebración (a diferencia de lo que exige el artículo $56 \mathrm{CC}$ para los matrimonios en forma civil) y dispone que la calificación del encargado del Registro Civil se realice previamente a su inscripción,
} 
ello, se produce desde ese momento un distanciamiento entre tales uniones y las canónicas por lo que se refiere a la comprobación por el Estado de los requisitos civiles de capacidad ${ }^{29}$. Tal como dispone el apartado segundo del artículo 7 de los Acuerdos con la FEREDE y FCI con idéntica letra, «[1] as personas que deseen contraer matrimonio en la forma prevista en el párrafo anterior promoverán el expediente previo al matrimonio, ante el encargado del Registro Civil correspondiente», quien, como sigue diciendo el apartado tercero, una vez cumplido dicho trámite expedirá la certificación acreditativa de la capacidad matrimonial que los contrayentes deberán entregar al ministro de culto encargado de la celebración del matrimonio.

Por tanto, de forma similar a lo que ocurre en el matrimonio en forma civil, debe tramitarse preceptivamente un expediente de capacidad ante autoridad civil competente con el fin de acreditar que los contrayentes gozan de la aptitud requerida para contraer matrimonio válidamente. La instrucción del mismo se rige por lo dispuesto en los artículos 238 y siguientes del $\mathrm{RRC}^{30}$, con la peculiaridad de que en estos casos el expediente no finaliza con la autorización del matrimonio, sino con la expedición por duplicado de la certificación de capacidad ${ }^{31}$. La

pudiendo denegarse la misma cuando de los documentos presentados y de los asientos del Registro conste que el matrimonio no reúne los requisitos civiles de validez. Como señala LóPEZ ALARCón, M., op. cit., p. 184, en virtud de este sistema «la calificación en la fase anterior a la celebración la hace el ministro religioso conforme a las normas de su propia confesión, si bien el artículo 63.2 del Código le obliga indirectamente a calificar los requisitos civiles que son susceptibles de exteriorizarse a través de la certificación que ha de trasladarse al Registro Civil y de los asientos de este, que en la práctica se reduce a la calificación de la edad civil para contraer matrimonio».

${ }^{29}$ No obstante, compartimos la opinión de GALlego DomíngueZ, I./GALÁn SOLDEVILLA, L., op. cit., p. 231, acerca de que tal exigencia impuesta por los Acuerdos no plantea problemas de acomodación en nuestro sistema jurídico, ya se entienda su posibilidad bajo el artículo $59 \mathrm{CC}$ «en los términos acordados con el Estado», ya se entienda que al haber sido aprobados por Ley tales Acuerdos y tener el Código Civil rango también de Ley, pueden tales leyes realizar la innovación señalada que lógicamente afectará solo a los matrimonios que contemplan los Acuerdos.

30 Así lo establece claramente la Instrucción de la DGRN 1993.

31 Otras peculiaridades de este expediente las señala Ramírez NAVALón, R.M., «Los matrimonios religiosos acatólicos: relevancia del expediente previo de capacidad e inscripción en el Registro Civil», en Estudios jurídicos en homenaje al profesor Enrique Lalaguna Domínguez, coord., J. Alventosa del Río/R.M. Moliner Navarro, vol. 2, 2008 , p. 906. Merece destacarse el hecho de que en los Acuerdos el plazo de caducidad del certificado de capacidad es de 6 meses, mientras que el artículo 248 RRC fija un plazo de validez de 1 año para el expediente matrimonial, contrasentido del que da cuenta la doctrina que aboga por la ampliación del primer plazo para equipararlo con el 
vigencia de esta certificación es de seis meses dentro de los cuales se debe celebrar el matrimonio para que sea válido (art. 7.4), condición que no se establece para los matrimonios por el rito islámico ${ }^{32}$. De hecho, respecto a estos últimos, el artículo 7 del Acuerdo con la CIE ni siquiera hace referencia al expediente matrimonial que deben promover los contrayentes ${ }^{33}$. No obstante, y como no podía ser de otro modo, también se exige imperativamente que acrediten reunir los requisitos de

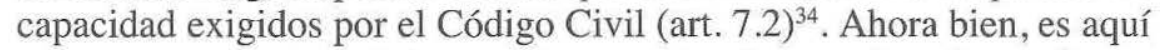
donde surge el primer interrogante respecto a los matrimonios en forma islámica: ¿cuándo deberán acreditarlo? El artículo 7.2 dispone, en su primera parte, que las personas que deseen inscribir el matrimonio celebrado en la forma prevista en el número anterior, esto es, ante dirigente religioso islámico o imán y al menos dos testigos mayores de edad, deberán acreditar previamente su capacidad matrimonial, mediante certificación expedida por el Registro Civil correspondiente. Por tanto, parece que esa acreditación se deberá hacer previamente a la inscripción del matrimonio y no a su celebración, a diferencia de lo que señalan los Acuerdos con las otras dos confesiones. Ahora bien, la segunda parte del precepto complica las cosas al disponer que «[n]o podrá practicarse la inscripción si se hubiera celebrado el matrimonio transcurridos más de seis meses desde la expedición de dicha certificación», de donde parece inferirse que la certificación de la capacidad debe ser previa a la celebración y no previa a la inscripción.

¿Cómo debe interpretarse la contradicción en la que incurre este apartado? ¿debe entenderse que el certificado de capacidad matrimonial es requisito para la válida celebración del matrimonio islámico o lo es

segundo. Criticando este plazo y manteniendo que sería más lógico establecer el de 1 año, CARrión Olmos, S., op. cit., p. 104, o Alenda Salinas, M., op. cit., p. 9202.

32 Tampoco para los matrimonios en forma civil o canónica. Respecto a los primeros, el artículo $56 \mathrm{CC}$ impone la necesidad del expediente matrimonial previo, pero no dispone que en caso de no instarlo el matrimonio sea inválido. Dicha falta tampoco se recoge en el artículo $73 \mathrm{CC}$ entre las causas de nulidad matrimonial.

${ }^{33}$ No obstante, un sector doctrinal considera que el silencio del artículo 7 respecto al expediente matrimonial es solo aparente e irrelevante, si se tiene en cuenta que la forma legítima de expedir la certificación de capacidad es tramitando previamente el expediente. En este sentido, Martinell, J.M./Areces Piñol, M.T., op. cit., p. 927 o Gallego Domínguez, I./Galán Soldevilla, L., op. cit., p. 230.

${ }^{34}$ Incluso hay quien opina que la necesidad de acreditar los requisitos de fondo civiles se subraya con trazos más enérgicos en el Acuerdo con la CIE puesto que el artículo 7.1 subordina expresamente la atribución de efectos civiles a que los «contrayentes reúnan los requisitos de capacidad exigidos por el Código Civil». En este sentido, Carrión Olmos, S., op. cit., p. 102 y Alenda Salinas, M., op. cit., p. 9193. 
solo para su inscripción? ${ }^{35}$ Un sector de la doctrina considera que no tiene demasiado sentido certificar la capacidad a posteriori, esto es, una vez celebrado el matrimonio, si se tiene en cuenta que lo que se pretende con dicha certificación es comprobar que los contrayentes reúnen los requisitos de capacidad necesarios para evitar que su matrimonio incurra en causa de nulidad. Si la capacidad ha de ser objeto de certificación es porque el matrimonio todavía no se ha celebrado, ya que, en caso contrario, no sería necesario que el encargado del Registro expidiera certificado alguno (como literalmente impone el art. 7.2), sino que sería suficiente para practicar el asiento con que, una vez promovida la inscripción, comprobara que los contrayentes reunían los requisitos de capacidad en el momento de la celebración del matrimonio y que se respetó la forma acordada. Por tanto, en base a esta postura, la interpretación lógica sería mantener que en estos casos también se precisa certificado de capacidad matrimonial previo a la celebración del enlace, tal y como se desprende indirectamente del inciso final del artículo 7.2 del Acuerdo con la $\mathrm{CIE}^{36}$.

A pesar de que esta interpretación no nos parece desacertada (pues tiene mucho más sentido que la capacidad deba acreditarse antes de la celebración), lo cierto y verdad es que, como afirma Rodríguez Chacón, el artículo 7.2 Ley 26/1992 se ha redactado en términos tales que, permitiendo acogerse al trámite previo del expediente, no lo hace obligatorio $^{37}$. Por tanto, el matrimonio celebrado por el rito islámico, de forma

${ }^{35}$ Que la letra de este artículo es ambigua porque parece consagrar sistemas diferentes respecto al control sobre la concurrencia o no de los requisitos de fondo exigidos por la legislación civil sustantiva, es algo en lo que está de acuerdo la doctrina de forma unánime. Entre otros, ALDANONDO SALAVERRÍA, I., op . cit., p. 379, RAMírEZ NAVALÓN, R.M, op. cit., p. 911, CARrión Olmos, S., op. cit., p. 103, GarCía VARELA, R., «La inscripción en el Registro Civil del matrimonio celebrado en forma religiosa», en Homenaje a Don Antonio Hernández Gil, coord. L. Martínez-Calcerrada y Gómez, vol. 3, 2001, p. 2457.

${ }^{36}$ Manteniendo esta postura, Martinell, J.M./Areces PIÑol, M.T., op. cit., p. 926, Gallego DomíngueZ, I/Galán Soldevilla, L., op. cit., p. 232, RamíreZ NAVALÓN, R.M, op. cit., p. 912, CARRIÓN OlMOS, S., op. cit., p. 103, RODRÍGUEZ CHACÓN, R., op. cit., p. 717, GARCÍA VARELA, R., op. cit., p. 2457 y ALdANONDO SALAVERría, I., op. cit., pp. 379-380. La DGRN mantiene que celebrado el matrimonio según el rito coránico, carece de sentido el expediente tramitado para la expedición del certificado de capacidad matrimonial. Lo procedente es que el encargado del Registro Civil competente califique si es inscribible ese matrimonio islámico celebrado en España. Vid., por todas, las Resoluciones de 17-1-2003 o de 22-1. a de abril de 2002.

37 Rodríguez Chacón, R., op . cit., p. 712. Para este autor, «lo que en los otros dos acuerdos era, pues, condición de celebración válida, se convierte aquí en requisito de inscripción, lo que es muy distinto». Vid., p. 717. 
similar al celebrado por el rito católico, no precisa para su validez de la tramitación de un expediente civil previo. Será en el momento en que se promueva la inscripción cuando, si no se hizo antes, se deberán acreditar los requisitos de capacidad exigidos por el Código Civil y el respeto de la forma acordada de celebración.

Esta es la interpretación que mantuvo la Dirección General de Registros y del Notariado en su Instrucción de 10 de febrero de 1993 sobre inscripción de determinados matrimonios celebrados en forma religiosa $^{38}$ (en adelante, la Instrucción) donde dispuso, con el fin de aclarar la ambigüedad del artículo 7, que quienes quisieran contraer matrimonio islámico podrían acudir al mecanismo del expediente previo a la celebración para obtener la consiguiente certificación acreditativa de la capacidad matrimonial -opción que calificaba de «especialmente aconsejable» para facilitar la posterior inscripción-, pero también podrían proceder a celebrar directamente el matrimonio religioso sin acudir previamente al Registro Civil - opción que no se concedió a los matrimonios evangélicos y judíos-. A esta interpretación llega, según expresa el propio Centro Directivo, comparando el texto de este precepto con el del artículo 7 de los dos restantes Acuerdos y, sobre todo, teniendo en cuenta los antecedentes de la negociación ${ }^{39}$.

Ahora bien, la DGRN no se queda ahí, sino que además estima que ni siquiera será necesario el certificado de capacidad matrimonial exigido por el artículo 7.2 para practicar la inscripción, sino que será el certificado de la celebración del matrimonio el único título necesario que servirá de base para llevarla a cabo ${ }^{40}$. Por tanto, según esta interpretación, en el caso del matrimonio islámico el certificado de capacidad vendría a carecer de virtualidad desde el momento en que no sería ni un requisito para la válida celebración del enlace, ni para su inscripción.

${ }^{38}$ BOE 24 de febrero de 1993, n. ${ }^{\circ} 47$, p. 5881.

39 Durante las negociaciones de este Acuerdo se trataron de aunar los intereses encontrados del Estado y de la Comisión Islámica. Mientras esta última reivindicaba la posibilidad de que su matrimonio pudiera alcanzar eficacia civil incluso en el caso de no existir expediente matrimonial previo a la celebración (tal como ocurre con el matrimonio en forma canónica), el Estado abogaba por la necesidad de que quedara acreditada la capacidad civil de los contrayentes. El resultado fue un texto ambiguo e impreciso cuya peculiar redacción (diferente a la de los otros dos Acuerdos) se debió en parte también a que el proceso de negociación con la Comisión Islámica se llevó a cabo en un momento distinto al de la negociación con las otras dos confesiones y de forma apresurada.

40 Así lo dispone la Instrucción en su ap. $4 .^{\circ}$ - párrs. $3 .^{\circ}$ y $4 .^{\circ}-$, dejando sin efecto la forma de acreditar la capacidad (esto es, la certificación expedida por el Registro), pero no la acreditación misma. 
Como puede fácilmente inferirse, la situación es muy distinta a la prevista para los matrimonios evangélicos o judíos que se celebran sin tramitar expediente previo o caducado el certificado de capacidad, los cuales, a tenor del artículo 7.4 de los Acuerdos, carecerían de validez. A esta cuestión dedicaremos el siguiente apartado.

\section{Situación jurídica del matrimonio celebrado sin tramitar} expediente previo o caducado el certificado de capacidad matrimonial

\section{a) Matrimonios en forma evangélica y judía}

Dos posturas se han mantenido acerca de la situación en la que se encuentran los matrimonios celebrados en forma evangélica y judía sin haber tramitado expediente previo o con certificado caducado: por un lado, la de aquellos que entienden que de la interpretación literal del artículo 7.4 no puede derivarse más que la nulidad del matrimonio sin posibilidad de subsanación ex $\operatorname{post}^{41}$; por otro lado, la de aquellos que consideran que a pesar de tales defectos el matrimonio no tendría que devenir necesariamente nulo, siempre y cuando hubieran concurrido los requisitos de validez ${ }^{42}$. Para los primeros, los Acuerdos con las confesiones acatólicas modifican el régimen del Código Civil añadiendo, como requisitos adicionales de validez del matrimonio evangélico y judío, la tramitación del expediente matrimonial civil y la celebración del mismo dentro de los seis meses siguientes a la emisión del certificado de capacidad. En su opinión, el hecho de que el Código Civil no enumere entre las causas de nulidad matrimonial la falta de expediente matrimonial previo no es argumento bastante para admitir la posibilidad de subsanación posterior, porque «ni en el Código Civil ni en la Ley de Registro Civil hay un precepto semejante a los artículos 7.4 de los Acuerdos evangélico e israelita, que claramente supediten la "validez civil" de los

${ }^{41}$ Defienden que en esos casos la unión es civilmente irrelevante, entre otros, Rodríguez Chacón, R., op. cit., pp. 710-711, CARrión Olmos, S., op. cit., p. 103, Martinell, J.M./Areces Piñol, M.T., op. cit., p. 923, FernándeZ-Coronado, A., op. cit., p. 358.

42 Ramírez navalón, R.M., op. cit., p. 908, Aldanondo Salaverría, I., op. cit., p. 382, López Alarcón, M., op. cit., p. 188, Gallego Domínguez, I./Galán SoldeVILLA, L., op. cit., pp. 240-241, DURÁN RIVACOBA, R., «El expediente...», cit., p. 3142 y ss, Albaladejo García, M., Curso de Derecho civil, vol. IV, 2008, p. 41, Serrano GómEz, E., «La celebración del matrimonio» en Tratado de Derecho de Familia, cit., Navarra, 2011, p. 550. 
matrimonios celebrados ante sus ministros de culto a la emisión del consentimiento precisamente dentro de los seis meses siguientes a la expedición del certificado de capacidad matrimonial. Otra cosa es que el efecto pueda parecer excesivo (sobre todo si se tiene en cuenta que ese efecto no se produce en el caso del matrimonio islámico)» ${ }^{43}$. Para los segundos, por el contrario, la existencia de tal certificación no es un requisito esencial, ni una formalidad ad solemnitatem para celebrar el matrimonio, sino que es un trámite previo que en caso de faltar no invalida per se el matrimonio como tampoco lo hace cuando el mismo se contrae en forma civil. Por tanto, estos autores no consideran que una persona hábil para el matrimonio pueda ver anulado el mismo por un aspecto formal que ni siquiera aparece contemplado en el Código Civil ${ }^{44}$.

\section{b) Matrimonios en forma islámica}

Por lo que se refiere a los matrimonios en forma islámica, el artículo 7.1 del Acuerdo supedita claramente la producción de efectos del matrimonio a que los contrayentes reúnan los requisitos de capacidad exigidos por el Código Civil. Por ello, un sector doctrinal considera que mientras no se solicite la inscripción y se compruebe la concurrencia de tales requisitos, el matrimonio no despliega efectos civiles y queda confinado al puro aspecto religioso ${ }^{45}$. No obstante, consideramos que esta postura no es la más acertada si se tiene en cuenta que, según el precepto citado, el matrimonio despliega efectos desde su celebración si los contrayentes gozan de capacidad matrimonial, sin ningún otro requisito. Por tanto, a nuestro modo de ver, desde el momento en que se presta el consentimiento en forma y con la capacidad legal necesaria, el matri-

43 Así Rodríguez CHACón, R., op. cit., p. 711.

44 En este sentido se expresan Gallego Domínguez, I./Galán Soldevilla, L., op. cit., p. 240. A pesar de ello, no restan importancia a tal certificación puesto que es la mejor manera de garantizar la celebración de un matrimonio válido.

${ }^{45}$ Así Rodríguez CHACón, R., op. cit., p. 720. En su opinión, no basta con que los contrayentes reúnan los requisitos de fondo y forma para que el matrimonio islámico goce de efectos civiles, ya que, por voluntad de los contrayentes, la realización de esos ritos religiosos puede no tener más intencionalidad que la de quedar circunscrita al mero ámbito intrarreligioso. Una vez inscrito, la unión surtiría efectos retroactivos desde la celebración, sin perjuicio de las responsabilidades a que haya lugar o de los derechos adquiridos de buena fe por terceros (ex art. 7.5). Y según CEBRIÁ GarCía, M.D, «La inscripción de los matrimonios religiosos no católicos en el Registro Civil», Familia: Revista de ciencias y orientación familiar, n. ${ }^{\circ} 19,1999$, p. 92, si no se inscribe, el Estado lo considera una unión de hecho. 
monio es válido y eficaz (si bien no frente a terceros de buena fe, sí inter partes), con independencia de que se hubiese instado o no la inscripción registral o de que se hubiese promovido o no expediente previo ${ }^{46}$. Es decir, con independencia al fin y al cabo de que los organismos oficiales del Estado tengan constancia o no del matrimonio celebrado ${ }^{47}$. Cuestión distinta es que, si no se acredita la condición de cónyuge legítimo (por medios registrales o extrarregistrales), no puedan hacerse valer los derechos inherentes a la misma, asunto que trataremos más adelante.

\section{c) Consideraciones sobre la cuestión a tenor de las modificaciones operadas por la LJV}

¿Sería extrapolable a los matrimonios de las otras dos Confesiones la solución que acabamos de exponer para los matrimonios islámicos teniendo en cuenta el tenor literal de los Acuerdos? Esto es, ¿podría mantenerse la validez de un matrimonio evangélico o judío a pesar de no haberse instruido el correspondiente expediente matrimonial?

Si se considera que el principal presupuesto de existencia y validez de cualquier matrimonio es el consentimiento prestado en forma y con la capacidad legal necesaria, no habría razón para privar de efectos al matrimonio así contraído por el solo hecho de no haberse tramitado expediente previo ${ }^{48}$. Menos aún, cuando tramitado y obtenido el certifi-

46 Así lo entiende también la DGRN. Vid., entre otras, las Resoluciones de 13-9-

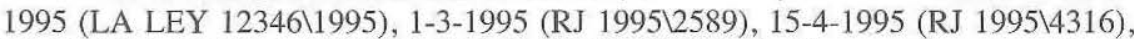
20-12-1996 (RJ 1997\8279) o 11-1-1999 (RJ 1999\10170). Con esta interpretación se salvaría el inconveniente puesto de relieve por RODRÍGUEZ CHACón, R., op. cit., p. 720, quien reconoce que la solución a la que llega, esto es, considerar que hasta la inscripción el matrimonio islámico no despliega efectos, no favorece la seguridad jurídica porque permite que alguien contraiga más de un matrimonio ante imán o dirigente islámico y elija en un momento dado inscribir uno de ellos, que no tiene por qué ser precisamente el primero.

${ }^{47}$ Como observa agudamente Alenda Salinas, M., op. cit., p. 9211, con esta previsión los islámicos pueden haber caído en su propia trampa porque los términos del Acuerdo les pueden llevar a lo que trataban de evitar (que no era más que salvar ¿penalmente?) sus matrimonios religiosos y hacer valer civilmente el que quisieran mediante la inscripción. El matrimonio islámico podrá gozar de efectos civiles, aunque los contrayentes no los quisieran (a diferencia para este autor de aquellos que contraigan por el rito evangélico o judío, a quienes les bastaría con no tramitar expediente previo para evitar los efectos civiles).

${ }^{48}$ Sobre la prevalencia que históricamente ha tenido el consentimiento como elemento esencial y verdaderamente constitutivo del matrimonio y el carácter instrumental de la forma, puede verse Polo SABAU, J.R., op. cit., pp. 29 y ss. También en el Derecho 
cado de capacidad, este hubiera caducado. Además, si así se hiciese, estos matrimonios quedarían en una situación peor que los matrimonios en forma canónica, islámica y civil, los cuales no serían necesariamente nulos y podrían inscribirse, bien a través del artículo 63.2 CC (los canónicos), bien del artículo $65 \mathrm{CC}$ (los islámicos y civiles). Y es que, como apunta con acierto Durán Rivacoba, el limitado alcance del control previo a través del expediente no garantiza la validez del matrimonio aprobado tras el mismo, y su omisión tampoco implica la ilicitud o nulidad del matrimonio contraído ${ }^{49}$.

Esta postura garantiza en mayor medida el principio de igualdad, el de favor matrimonii y el de conservación del negocio jurídico. Pero no puede obviarse que la postura de aquellos que mantienen la invalidez (o ineficacia) del matrimonio contraído sin haber tramitado expediente previo garantiza mejor la seguridad jurídica puesto que evita la celebración de matrimonios nulos que no podrían llegar a inscribirse ${ }^{50}$. El principal inconveniente que se ha objetado a esta postura es que deja en manos de los contrayentes la eficacia civil del matrimonio. Esto es, bastaría con que los contrayentes no promoviesen expediente para privar de efectos civiles al enlace. Y ello incluso en el caso de que, por concurrir los requisitos de fondo, pudiera tenerlos ${ }^{51}$.

Pues bien, no podemos ignorar que el artículo $60.2{ }^{\circ} \mathrm{CC}$, en su redacción dada por la reciente $\mathrm{LJV}$, condiciona el reconocimiento de eficacia civil a los matrimonios de las Confesiones con notorio arraigo, al cumplimiento de dos requisitos: la tramitación del acta o expediente

inglés este elemento es el fundamental. Vid., Probert, R., op. cit., p. 81. Según explica la autora, aunque generalmente se asume que una pareja está casada desde que el oficiante los declara marido y mujer - e incluso en una consulta que se hizo al Gobierno inglés se estableció que esto debía de ser así-, en virtud de la ley vigente, desde el momento en que los contrayentes consienten, el matrimonio despliega efectos. Por ello, la mujer que cambió de opinión después de sus votos, pero antes de que el sacerdote los declarara marido y mujer, actuó demasiado tarde puesto que el matrimonio ya era eficaz.

49 DURÁN RIVACOBA, R., «El expediente civil previo a la celebración del matrimonio en la reforma del Reglamento del Registro Civil», $A C$, n. $^{\circ} 3,1989$, p. 3142, siguiendo a AREChederRa. En sentido similar, entre otros, Gallego Domínguez, I./ Galán Soldevilla, L., op. cit., p. 241 o Alenda Salinas, M., op. cit., p. 9207.

${ }^{50}$ En este sentido, vid., Aldanondo Salaverría, I., op. cit., p. 384.

${ }^{51}$ Como matizan Martinell, J.M./Areces PiÑol, M.T., op. cit., p. 924, «esa iniciativa significa, no exactamente, que la eficacia civil dependa de la voluntad de las partes - porque eso depende también de otras condiciones - pero sí que queda reservado a la autonomía privada de las partes que ese matrimonio religioso que se disponen a contraer carezca de eficacia civil, incluso en el caso de que, por concurrir las condiciones de fondo, pudiera tenerla». 
previo a la celebración y la manifestación del consentimiento ante ministro de culto acreditado y dos testigos mayores de edad. A sensu contrario podría inferirse, que la falta de alguno de estos requisitos impediría que el matrimonio desplegara efecto alguno.

¿Avala esta nueva disposición la postura de aquellos que defendían la necesidad de tramitar expediente previo como condición de validez o eficacia civil del matrimonio evangélico y judío?

Para responder esta cuestión debe tenerse en cuenta una idea básica: cuando el artículo $61 \mathrm{CC}$ señala que «el matrimonio produce efectos desde su celebración», está partiendo de un matrimonio válido, esto es, celebrado conforme a los requisitos civiles. Ahora bien, parece que esos requisitos civiles no son los mismos en todos los casos. Por lo que se refiere a los matrimonios celebrados en alguna de las nuevas formas religiosas admitidas, el legislador ha incluido - al parecer como requisito sustancial - la tramitación del acta o expediente previo de capacidad matrimonial. Por tanto, no bastaría con prestar el consentimiento ante el ministro de culto de la confesión correspondiente y dos testigos mayores de edad, y con cumplir los requisitos civiles de fondo, sino que habría que cumplir otro requisito adicional para que el Estado reconociese efectos al enlace: la tramitación del acta o expediente previo de capacidad.

Dicha instrucción se llevará a cabo a instancia de los contrayentes, tal y como dispone el nuevo artículo 58.2. ${ }^{\circ} \mathrm{LRC}$ (al que remite el art. 58 bis). Por tanto, se podría esgrimir en este caso el mismo reproche que venía manteniendo la doctrina respecto a los matrimonios evangélicos y judíos contraídos sin tramitar expediente, esto es, que por iniciativa propia de los contrayentes se podría privar de eficacia civil a un matrimonio, aun cuando pudiera tenerla por concurrir las condiciones de fondo y haberse prestado el consentimiento en la forma legalmente fijada. Nos encontraríamos así con matrimonios a los que no se les reconocerían efectos civiles, a pesar de haberse respetado las mínimas exigencias que garantizan la seguridad y certeza en la mutua manifestación del consentimiento marital.

Para evitar estas anómalas e indeseables situaciones creemos que se podrían adoptar dos soluciones: por un lado, sería necesario, o cuanto menos conveniente, que los ministros de culto colaborasen con el Estado y se negasen a celebrar matrimonios cuando los contrayentes no les entregasen previamente el certificado de capacidad ${ }^{52}$. Al menos, cuando

52 El deber de entregar al ministro de culto oficiante el acta o resolución sobre la capacidad matrimonial lo establece el nuevo artículo 58.2. ${ }^{\circ}$ bis y también lo establecía 
la forma de celebración que se quisiera respetar fuera la establecida por el Estado. En otro caso, esto es, si se pretendiese hacer uso del rito matrimonial de estas confesiones sin respetar la forma fijada en el artículo $60.2 .^{\circ}$.b) CC, el matrimonio no tendría efectos civiles al no haber respetado un requisito de forma sustancial, independientemente de que se hubiese tramitado o no expediente matrimonial previo.

En este sentido, el Derecho canónico ha previsto una serie de medidas entre las que destaca la prohibición dirigida a los ministros de culto católicos de asistir, sin licencia del Ordinario, a la celebración de matrimonios canónicos que no puedan ser reconocidos por la ley civil ${ }^{53} \cdot$ ¿Sería conveniente que el resto de Confesiones previeran medidas similares con el fin de prevenir la celebración de matrimonios civilmente ineficaces? Sin duda alguna sería aconsejable. Pero en defecto de las mismas, tampoco tenemos claro que el Estado no pudiera sancionar disciplinariamente a las Confesiones cuyos ministros de culto celebrasen matrimonios sin dicho trámite previo, en tanto que estos cumplen en cierta medida una función pública que les ha atribuido el Estado, de forma similar a lo que ocurre con los funcionarios civiles ${ }^{54}$. Además, respecto a las Confesiones con Acuerdo, dicha actuación podría considerarse un incumplimiento del mismo en virtud del cual el Estado debería de poder tomar las oportunas medidas ${ }^{55}$.

el artículo 7.3. ${ }^{\circ}$ Leyes 24/1992 y 25/1992. No así el artículo 7 de la Ley 26/1992, omisión debida a las diferencias en cuanto a la tramitación del expediente para los matrimonios islámicos.

53 Canon 1071.1. .

${ }^{54}$ Así lo entiende Ramírez Navalón, R.M, op. cit., p. 903. Sin embargo, AlEnda SALINAS, M., op. cit., p. 9215 , aun cuando reconoce que esta cuestión ha sido muy discutida, parece entender que no puede considerarse que el representante o ministro confesional sea órgano del Estado. En nuestra opinión, que creemos es la mantenida también por RAMíREZ, si bien es cierto que tales sujetos no son funcionarios del Estado, también lo es que este ha delegado en ellos una función pública como es la de asistir y certificar el matrimonio, cuyo incumplimiento debería de poder sancionarse. Y ello porque, ante el incumplimiento de las Confesiones, serán los contrayentes que desean que su matrimonio sea civilmente reconocido, los directamente perjudicados.

${ }^{55}$ Un sector de la doctrina considera que sin el certificado previo de capacidad, el ministro de culto ni siquiera estaría habilitado por el Estado para ejercer su función, motivo por el que estas uniones no podrían desplegar efectos. Ahora bien, sin perjuicio de lo anterior, consideran que las Confesiones podrían seguir asistiendo a sus fieles por cuanto que, aunque en principio deberían exigir el cumplimiento de los requisitos acordados, habría mecanismos para permitir la celebración de un matrimonio religioso que no fuera válido a tenor del artículo 7.4 de los Acuerdos. Así, entre otros, ALENDA SALinAS, M., op. cit., p. 9199, CARrión Olmos, S., op. cit., p. 104 o García VARELA, R., op. cit., p. 2457. Para Martinell, J.M./Areces Piñol, M.T., op. cit., p. 923, el Estado 
Por otro lado, una segunda solución para evitar matrimonios civilmente inválidos y no inscribibles a falta de certificado de capacidad previo, sería otorgar la posibilidad de subsanar dicho defecto. Y es que, a nuestro modo de ver, más allá de la polémica sobre si estos matrimonios deben considerarse válidos o nulos, lo que ocurriría es que no serían inscribibles. A tenor del nuevo artículo $58.2 .^{\circ}$ bis, párrafo tercero, la certificación del matrimonio celebrado en la forma prevista por alguna de las Confesiones con notorio arraigo, deberá contener, entre otras cosas, la mención de las circunstancias del acta o resolución de capacidad, documento este último que además debe entregarse por los contrayentes al ministro de culto antes de proceder a la celebración. $\mathrm{La}$ certificación matrimonial se remitirá por medios electrónicos, en la forma en que reglamentariamente se determine, junto con la certificación acreditativa de la condición de ministro de culto, dentro del plazo de cinco días al encargado del Registro Civil competente para su inscripción ${ }^{56}$. Por tanto, si la certificación del matrimonio no contiene los datos que imperativamente fija el precepto citado (çomo consecuencia de no haber instruido expediente previo a la celebración), ¿debería el encargado del Registro denegar la práctica del asiento en virtud del artículo $63 \mathrm{CC}$ (al que remite el art. 59.3. $\left.{ }^{\circ} \mathrm{LRC}\right)^{57}$, al no constar de los documentos presentados que el matrimonio reúne los requisitos que para su

no podría prohibir a las confesiones religiosas autorizar el rito matrimonial religioso sin certificado de capacidad, ni, por tanto, validez (eficacia) civil, sino que debería ser la propia Confesión la que se negara a autorizar dicho matrimonio, pero eso quedaría ya al margen del Derecho del Estado.

${ }^{56}$ El mismo procedimiento se ha establecido para los matrimonios evangélicos, judíos e islámicos en el artículo 7 de las Leyes 24, 25 y 26 de 1992. Vid., Disposiciones Finales 5 . $^{\mathrm{a}}, 6$. $^{\mathrm{a}}$ y 7 . $^{\mathrm{a}}$ LJV.

57 Dispone el artículo 59.3..$^{\circ} \mathrm{LRC}$ sobre la inscripción del matrimonio que «El matrimonio celebrado en España en forma religiosa accederá al Registro Civil mediante la inscripción de la certificación emitida por el ministro de culto, conforme a lo previsto en el artículo 63 del Código Civil». La redacción de este artículo se ha modificado mínimamente por la LJV pero sin alterar su contenido. La remisión al procedimiento registral previsto en el artículo $63.2 \mathrm{CC}$ se entiende si se parte de que en dicha certificación deben hacerse constar los requisitos de inscripción y las menciones de identidad de los testigos y de las circunstancias del acta o expediente previo de capacidad. Esto justificaría ese control atenuado por parte del encargado del Registro, en la medida en que ya se habría comprobado previamente el cumplimiento de los requisitos civiles de fondo. Como señala García CANTERo, G., op . cit., p. 164, el encargado no entra a juzgar a fondo sobre la validez del vínculo, ni emite resolución alguna sobre su existencia o inexistencia, sino que únicamente toma en cuenta para denegar la inscripción la prueba documental consistente en la certificación presentada y en los asientos de su Registro. 
validez se exigen en el Código Civil? ¿o este problema de inscripción podría subsanarse mediante la comprobación de la capacidad por la vía del artículo $65 \mathrm{CC}$ antes de permitir la inscripción?

La redacción del artículo $65 \mathrm{CC}$ ha sido recientemente modificada por la LJV. Según señala el precepto, cuando el matrimonio se hubiera celebrado sin haber tramitado el correspondiente expediente o acta previa, si este fuera necesario, el mismo podría llegar a inscribirse una vez comprobados los requisitos de validez previamente a la inscripción. Se dice expresamente ahora que dicha comprobación deberá hacerse mediante la tramitación de acta o expediente previo a la inscripción. Y en el mismo sentido se pronuncia el artículo 58.10. ${ }^{\circ}$ LRC. Sin embargo, no encontramos una disposición similar en el artículo 58 bis que es el que se refiere a los matrimonios en forma religiosa, omisión que suscita dudas acerca de si es posible o no inscribir estos matrimonios a través de expediente previo a la inscripción. ¿Se podría acudir en estos casos al artículo 65 CC? Sobre la aplicación de este precepto a los matrimonios religiosos distintos del canónico celebrados sin tramitar expediente previo, la doctrina ha venido sosteniendo opiniones diversas en función de la postura mantenida respecto a la validez o nulidad del enlace así contraído: para unos, aunque el artículo $65 \mathrm{CC}$ no esté dictado para estos casos, su doctrina sí les es aplicable (con más razón ahora que se ha eliminado la salvedad que contenía la redacción anterior respecto a los matrimonios religiosos). En consecuencia, a falta de expediente previo o caducada la certificación, consideran que ese matrimonio sería inscribible en virtud de expediente subsanador mediante el que quede acreditada la celebración en forma del matrimonio y la inexistencia de impedimentos ${ }^{58}$. Para otros, el artículo $65 \mathrm{CC}$ solo sería aplicable al matrimonio islámico puesto que es el único caso en que, en virtud de la Instrucción de la DGRN de 1993, se permite la celebración sin dicho trámite previo $^{59}$. En los otros casos, puesto que el incumplimiento de dicha formalidad acarrearía el no reconocimiento del matrimonio por el

58 Gallego Domínguez, I./Galán Soldevilla, L., op. cit., p. 240. También DuRÁN RIVACOBA, R., «El expediente...», cit., p. 3144, considera que, a pesar de que la DGRN ha establecido que el artículo 65 se aplica a los supuestos de matrimonio contraído en peligro de muerte, no puede rechazarse la aplicación del artículo 65 a los supuestos en los cuales se haya procedido a la celebración sin comprobar la efectiva práctica de dicho expediente, luego descubierta - su omisión - a la hora de inscribir.

${ }^{59}$ Díez del Corral Rivas, J., «Comentarios a los artículos 255 y siguientes del RRC», en Comentarios al Código Civil y Compilaciones Forales, tomo IV, vol. 5, p. 494, y CRESPO MORA, M.C., «La celebración del matrimonio», en Derecho de Familia, cit., p.431. 
Estado, no cabría la comprobación de la capacidad ex post. Y ello, porque es evidente que no puede subsanarse algo que ni siquiera existe.

A nuestro modo de ver, en defecto de acta o expediente previo debería darse la opción de tramitarlo a posteriori para conseguir la inscripción. Y ello porque, mientras quede acreditado el cumplimiento de los requisitos esenciales del matrimonio (consentimiento prestado en forma acordada y capacidad de los contrayentes), el matrimonio sería válido y debería reconocerse al margen de que dicha acreditación se llevara a cabo antes o después de su celebración. No obstante, no queda claro que esta sea la opción por la que se ha decantado el legislador, a la vista de la redacción que a través de la reciente LJV se ha dado a los artículos 60.2 CC y 58 bis LRC. ¿Prevalece para el Estado la seguridad jurídica sobre el principio de favor matrimonii? ¿o simplemente se pretende facilitar la compleja tarea del registrador?

\section{LA INSCRIPCIÓN DEL MATRIMONIO RELIGIOSO ACATÓLICO EN EL REGISTRO CIVIL: PARTICULAR REFERENCIA AL MATRIMONIO ISLÁMICO}

\section{Título de inscripción, calificación y procedimiento registral}

Las diferencias anteriormente analizadas respecto a la fase preparatoria de estos matrimonios, inciden en gran medida en la forma en que habrá de procederse a su inscripción en el Registro Civil. Es decir, no se procederá de la misma manera en caso de que se haya tramitado expediente matrimonial previo y haya culminado con la obtención del certificado de capacidad, que en caso de que éste falte o haya caducado.

Respecto al título necesario para la inscripción, tanto los Acuerdos como posteriormente la Instrucción de la DGRN que los interpreta, modificaron sustancialmente el régimen previsto en el Código Civil. Mientras el artículo $63 \mathrm{CC}$ consideraba suficiente para proceder a inscribir cualquier matrimonio en forma religiosa, la simple presentación de la certificación de la Iglesia o confesión respectiva donde se expresan las circunstancias exigidas por la legislación del Registro Civil ${ }^{60}$, los Acuerdos establecieron un título complejo formado por dos certificados: el certificado de capacidad expedido por autoridad civil y el certi-

60) También en esta línea el artículo 59.3 LRC 20/2011, cuya redacción ha sido mínimamente modificada por la LJV pero sin variar su contenido. Solo se añade, junto a las Iglesias o confesiones, a las «comunidades religiosas o federaciones respectivas. 
ficado de celebración del matrimonio expedido por autoridad eclesiástica. Más concretamente, el artículo 7.5 de los Acuerdos con la FEREDE y con la FCI dispuso que en la certificación de capacidad el ministro de culto oficiante extendería diligencia expresiva de la celebración del matrimonio que contendría los requisitos precisos para su inscripción y las menciones de identidad de los testigos, $\mathrm{y}$ uno de los ejemplares de dicha certificación diligenciada sería remitido al Registro para su inscripción ${ }^{61}$. Y aunque en el artículo 7.3 del Acuerdo con la CIE no se indicaba que la certificación del matrimonio hubiera de hacerse como diligencia en la certificación de capacidad, un sector de la doctrina entendió que la referencia a la certificación diligenciada que contenía el apartado cuarto, llevaba a concluir que también en los matrimonios islámicos había que proceder de la misma manera ${ }^{62}$.

Sin embargo, no fue esta la interpretación que siguió el Centro Directivo en su Instrucción de 1993, donde permitió, como novedad, que excepcionalmente en los matrimonios islámicos se prescindiera del certificado de capacidad matrimonial para practicar la inscripción, bastando en estos casos con el certificado de la celebración del matrimonio para llevarla a cabo ${ }^{63}$.

Ahora bien, la labor calificadora del encargado será muy distinta en uno u otro caso. Esto es, en los casos en que, siguiendo la norma

${ }^{61}$ Por tanto, la certificación del matrimonio queda integrada en la de capacidad, como si fuera una segunda parte, constituyendo ambos el título de inscripción. De la Instrucción de la DGRN se desprende que sin este documento no puede inscribirse el matrimonio. Sobre la inscripción de estos matrimonios pueden verse, por ejemplo, las Resoluciones de la DGRN de 16-7-2012 (LA LEY 25089212012) o la de 10-2-2014 (LA LEY 9199812014).

${ }^{62}$ En este sentido se pronuncian, entre otros, Gallego Domínguez, I./Galán Soldevilla, L., op. cit., pp. 236-237 o CeBriá García, M.D., op. cit., p. 83.

${ }_{63}$ En base a esta interpretación, muy criticada por la doctrina en la medida en que se aparta del tenor literal del artículo 7.2 y 7.3 del Acuerdo con la CIE, en la práctica registral se viene admitiendo este certificado para la inscripción. Vid., entre otras, las Resoluciones de la DGRN de 17-5-1995 (RJ 1995\4360), y de 18-7-1996 (RJ 199619795). Cuestión distinta es que no siempre se considere que a través del mismo quede suficientemente acreditada la realidad o legalidad del matrimonio, denegándose por ello la práctica del asiento. Así ocurre en las Resoluciones de 19-5-2009 (JUR 2010\301896) y 30-9-2010 (JUR 2011\314744). Criticando la interpretación del Centro Directivo, entre otros, LóPEZ AlarCón, M., op. cit., p. 191, MARTinell, J.M./ARECES PiÑol, M.T., op . cit., pp. 925 y 928, nota 23 y MARCHAL ESCALONA, N., «Matrimonio religioso y la Instrucción de 10 de febrero de 1993 de la Dirección General de los Registros y del Notariado», La Ley: Revista jurídica española de doctrina, jurisprudencia y bibliografía, n. ${ }^{\circ} 6,1996$, p. 8. Para todos ellos se trata de una interpretación contra legem que no debería de prevalecer. 
general, se haya tramitado expediente previo a la celebración y se cuente con el certificado de capacidad matrimonial, la actividad del encargado «quedará notablemente facilitada porque, acreditada ya de antemano la capacidad de los contrayentes, habrá de limitarse a comprobar que no han transcurrido más de seis meses entre la expedición del certificado de capacidad y la celebración del matrimonio y que se han cumplido los demás requisitos formales exigidos por los Acuerdos» ${ }^{64}$. Por el contrario, en el caso excepcional de que, tratándose de matrimonios en forma religiosa islámica, los interesados prescindan bajo su responsabilidad del trámite previo de expedición del certificado de capacidad matrimonial, y, por tanto, contraigan matrimonio sin que se haya comprobado la concurrencia de los requisitos civiles (aunque se hayan cumplido los establecidos por la Ley islámica pues no olvidemos que las normas civiles y religiosas difieren en lo que a la capacidad para contraer matrimonio se refiere, y más aún, en el matrimonio islámico), la calificación del encargado no podrá limitarse a comprobar que concurrieron los requisitos formales exigidos por los Acuerdos (control formal) sino que deberá constatar con especial cuidado que los contrayentes del matrimonio ya celebrado reunían los requisitos de capacidad exigidos por el Código Civil, así como por las normas del Derecho Internacional privado español si uno o ambos fuesen extranjeros, debiéndose además ex-

${ }^{64}$ Apartado 4 párrafo 2. ${ }^{\circ}$ Instrucción. Según Rodríguez CHAcón, R., op. cit., p. 715, el encargado del Registro deberá comprobar que el ministro de culto asistente al matrimonio tiene el concepto de tal, de conformidad con el artículo 3 de los Acuerdos. Pero MARTíneZ RUBIO, A., «La inscripción del matrimonio islámico en el Registro Civil», $A D E E, \mathrm{n} .^{\circ} 19,2003$, pp. 275-276, matiza que la actividad calificadora se centra en que en la certificación figure un sello de la comunidad religiosa para posteriormente controlar que la misma forma parte de la Federación respectiva, con lo que en realidad no existe una calificación, stricto sensu, sobre el ministro de culto por la falta de datos que el propio Registro tiene sobre ello, ni sobre la persona que certifica, que generalmente es aquel. Respecto al control de la autenticidad del documento, la DGRN ha establecido que los criterios y orientaciones prácticas que en orden a la prevención del fraude documental en materia de estado civil se contienen en la Recomendación $n .^{\circ} 9$ de la Comisión Internacional del Estado Civil, relativa a la lucha contra el fraude documental en materia de estado civil, deben aplicarse analógicamente al caso de las certificaciones eclesiásticas de matrimonio. Entre dichas recomendaciones se incluye la de que «Cuando existan indicios que hagan dudar de la exactitud de los datos que figuran en el documento presentado o de la autenticidad de las firmas, el sello o el documento en sí mismo, la autoridad competente en el asunto realizará todas las comprobaciones necesarias, en particular con el interesado», y la de que «Cuando de los elementos verificados se desprenda el carácter fraudulento del documento presentado, la autoridad competente se negará a otorgarle efecto alguno». Vid., Instrucción de 20 de marzo de 2006 de la DGRN, sobre prevención del fraude documental en materia de estado civil. 
tremar el celo en estos matrimonios para asegurarse que no existe impedimento de ligamen (control sustantivo) ${ }^{65}$. Y es importante destacar que dicha comprobación no estará sujeta a las limitaciones probatorias que impone el artículo 63.2 CC para los matrimonios en forma religiosa, sino que deberá realizarse, según establece el Centro Directivo, con la amplitud de investigación que autoriza el artículo 65 CC y a través de los medios a que se refiere el artículo $256 \mathrm{RRC}^{66}$.

$\mathrm{El}$ artículo $256 \mathrm{RRC}$, en desarrollo del artículo $65 \mathrm{CC}$, prevé la posibilidad de inscribir el matrimonio sin expediente cuando el mismo esté justificado documentalmente a través de las actas o certificaciones que en él se detallan. Por tanto, si los contrayentes de un matrimonio islámico cuentan con el certificado eclesiástico que acredite la celebración del enlace, podrían llegar a inscribirlo sin necesidad de tramitar expediente ni previo ni posterior al enlace, sin perjuicio de que el encargado del Registro ejerciera su función comprobadora, previa a la calificación, antes de practicar la inscripción ${ }^{67}$. La calificación post factum se

${ }^{65}$ Así lo establece la Declaración 6. ${ }^{\text {a }}$ de la Instrucción. Esta cautela es necesaria teniendo en cuenta que el Derecho islámico permite la poligamia, inadmisible por el contrario en el Ordenamiento español por ser contraria a la dignidad de la mujer.

${ }^{66} \mathrm{El}$ artículo $65 \mathrm{CC}$ establece cómo ha de practicarse la inscripción cuando el matrimonio se ha celebrado sin haber tramitado expediente civil previo. En tales casos, y con el fin de evitar que puedan inscribirse en el Registro matrimonios que no cumplen los requisitos de validez legalmente establecidos, el encargado del Registro Civil tendrá que comprobar si los mismos concurren antes de practicar el asiento. Se trata de una comprobación positiva de la capacidad civil de los contrayentes frente al control negativo de legalidad que prevé el artículo $63.2 \mathrm{CC}$. Y es que, como matiza agudamente RODRÍGUEZ CHACón, R., op. cit., p. 719, no es lo mismo comprobar que los contrayentes reúnen los requisitos de capacidad exigidos por el Código Civil (que es lo que exige el art. 7.1 del Acuerdo con la CIE para los matrimonios islámicos sin expediente y el art. $65 \mathrm{CC}$ ), que llegar a la conclusión de que, de los documentos presentados o de los asientos del Registro, conste que el matrimonio no reúne los requisitos exigidos por el Código (que es lo que establece el art. 63.2 CC). Como advierte DuRÁn RIVACOBA, R., «El expediente...», cit., p. 3143, en la práctica, el ámbito de aplicación del artículo $63.2 \mathrm{CC}$ ha quedado reducido al matrimonio celebrado en forma canónica. Sobre el artículo 65 CC ténganse también en cuenta los comentarios realizados en el apartado segundo de este trabajo.

${ }^{67}$ Rodríguez Chacón, R., op. cit., nota 32, respecto a la situación real de los matrimonios religiosos en España, pone de manifiesto - partiendo de los trabajos de una alumna suya de doctorado - que «en algún Registro Civil (y no precisamente de pequeña población) vienen inscribiéndose sin expediente (ni previo ni ex post) los matrimonios islámicos cuya certificación se aporta al Registro. Al parecer, solo se solicita a los interesados una certificación consular con la que, en definitiva, se trata más bien de suplir las deficiencias de identificación de que normalmente adolecen las certificaciones religiosas islámicas que llegan al Registro». 
llevaría a cabo a través del examen de la certificación eclesiástica presentada y de las declaraciones complementarias oportunas (art. 256 in fine en relación con el art. 256.2) y solo procedería la inscripción cuando no hubiesen dudas de la realidad del hecho y de su legalidad conforme a la Ley española.

Ahora bien, la primera cuestión que nos surge a la vista de este procedimiento registral es la siguiente: ¿es suficiente con la certificación eclesiástica expedida por la Confesión y con las declaraciones complementarias para despejar cualquier duda acerca de la realidad del matrimonio y de su legalidad? Con otras palabras, ¿podrá el encargado del Registro a través de este título de inscripción comprobar la concurrencia de los requisitos de forma y capacidad legalmente exigidos?

La doctrina ha venido manifestando serias dudas acerca de que las circunstancias que han de constar en la certificación del matrimonio contengan datos suficientes para comprobar que concurren los requisitos civiles de validez ${ }^{68}$. Téngase en cuenta que, según señala la Instrucción DGRN, dicha certificación solo deberá expresar los datos previstos por la Orden 1993 y contener los requisitos formales establecidos por la legislación del RC, esto es, los previstos en los artículos 69 LRC y 258 $\mathrm{RRC}^{69}$. Por otro lado, respecto a la utilidad de las declaraciones complementarias para despejar las dudas acerca de la realidad y legalidad del matrimonio, los autores han mantenido opiniones contrapuestas.

68 Por todos, Martínez Rubio, A., op. cit., p. 282, o DurÁn Rivacoba, R., «El expediente...», cit., p. 3144.

69 Estas circunstancias son: acto del matrimonio, fecha, hora y lugar en que se contrae (ex art. 69 LRC 1957; art. 59 LRC 2011 - no menciona la hora-), menciones de identidad de los contrayentes, nombre, apellidos, cualidad del autorizante (art. 258.1 RRC). Gallego Domínguez, I./Galán Soldevilla, L., op. cit., p. 237, se preguntan si debería hacerse mención en la certificación de la celebración del matrimonio de los requisitos de validez civiles. Entiende que no es necesario que consten en la diligencia que certifica la celebración ya que esto se deducirá de la certificación de capacidad del Registro. Pero a nuestro modo de ver, estaría bien hacerlos constar para los casos en que no ha habido certificado de capacidad previo. Sobre esto debe tenerse en cuenta que la nueva redacción del artículo 7.3 de la Ley 26/1992 (y paralelamente del art. 7.5 Leyes 24 y 25) dada por la DF $5 .^{a}, 6$. $^{\mathrm{a}}$ y 7 . $^{\mathrm{a}} \mathrm{LJV}$, dispone expresamente que «Una vez celebrado el matrimonio, el representante de la Comunidad Islámica en que se hubiera contraído aquel extenderá certificación expresiva de la celebración del mismo, con los requisitos necesarios para su inscripción y las menciones de las circunstancias del expediente o acta previa que necesariamente incluirán el nombre y apellidos del secretario judicial, notario, encargado del Registro Civil o funcionario diplomático o consular que la hubiera extendido, la fecha y número de protocolo en su caso». Por tanto, con esta previsión se pretende que consten estos datos en la certificación matrimonial. 
Para unos, dichas declaraciones podrían ser muy útiles a efectos de calificar la capacidad de los contrayentes y de comprobar la ausencia de impedimentos (extremos difícilmente detectables con la sola certificación) y podrían concretarse, por ejemplo, en preguntas al representante de la Comunidad, al ministro de culto oficiante, a los contrayentes, o a las personas relacionadas con ellos ${ }^{70}$. Para otros, por el contrario, en la medida en que tales declaraciones no son en sí mismas un expediente stricto sensu sino actos de parte, sin necesidad de otros documentos (aunque el encargado pueda solicitar con base a ellas algún documento que considere oportuno), que se realizan sobre la certificación del matrimonio, la comprobación de la aptitud nupcial puede ser deficiente ${ }^{71}$.

Por tanto, si aún por esta vía no se consiguen disipar las dudas acerca de la realidad y legalidad del matrimonio con el fin de proceder a la inscripción, ¿procedería entonces su denegación con el consiguiente perjuicio para los contrayentes a los que se les priva de un título de legitimación que les permitiría ejercitar los derechos derivados del mismo? Por esta opción se decanta la Dirección General en varias de sus resoluciones a tenor de las cuales, la conclusión sobre la falta de realidad o legalidad del matrimonio «no quedaría desvirtuada por un expediente posterior (el del art. $257 \mathrm{RRC}$ ) del cual debe prescindirse por razones de economía procesal (art. 354 RRC) si es que se estima que, además de la vía judicial, quedara abierto este camino ante la denegación adoptada en la calificación efectuada por la vía del artículo 256 del Reglamento» ${ }^{72}$.

A nuestro juicio, si bien en ocasiones puede estar justificado alegar razones de economía procesal para evitar la práctica del expediente, no creemos que se deba recurrir a esta fórmula con carácter general. Por el contrario, si mediante la calificación efectuada por la vía del artículo $256 \mathrm{RRC}$ no se consiguen despejar las dudas sobre la realidad o legalidad del matrimonio, debería acudirse al mecanismo previsto en el artículo $257 \mathrm{RRC}$, esto es, a la tramitación de un verdadero expediente previo a la inscripción ${ }^{73}$.

${ }^{70}$ En este sentido, Díez del Corral Rivas, J., "Comentarios a los artículos $255 \ldots »$, cit., p. 498 o CEBRIÁ GARCía, M.D., op. cit., p. 92

${ }^{71}$ Así lo estima Martínez Rubio, A., op. cit., p. 282.

72 Vid., por ejemplo, las Resoluciones de 19-5-2009 (JUR 20101301896), 27-72009 (JUR 2010\352917), 30-9-2010 (JUR 2011\314744), o 12-12-2013 (LA LEY 254327 2013).

${ }^{73}$ Sobre este expediente y sus diferencias con el previo a la celebración, señala DurÁN RivacoBA, R., «El expediente...», cit., p. 3143, nota 64, que ambos son distintos en la forma y procedimiento (el previo al matrimonio se incoa por quienes aspiran 
El artículo $257 \mathrm{RRC}$ es complementario del anterior y debe aplicarse no solo cuando no existan las actas o certificaciones a que se refiere el artículo $256 \mathrm{RRC}$, sino también cuando existiendo las mismas haya dudas de la realidad o legalidad del matrimonio ${ }^{74}$. En ambos casos, el encargado deberá tramitar un expediente y este concluirá permitiendo la inscripción únicamente cuando se acredite debidamente la celebración en forma del matrimonio y la inexistencia de impedimentos. De hecho, algún autor ha constatado que en algunos Registros Civiles el control de legalidad de los matrimonios religiosos islámicos celebrados sin expediente previo y certificado de capacidad matrimonial, se lleva a cabo directamente a través de dicho expediente que es instado de oficio por el juez ${ }^{75}$.

a contraerlo, mientras el relativo a la inscripción se inicia de oficio, y solo le serán aplicables por analogía los instrumentos y diligencias de prueba de aquel, en virtud de lo cual estima Díez del Corral no constituir en sentido estricto un propio expediente, contra lo establecido por los arts. 65 y 257), en el tiempo (uno antes de contraer, el otro después), y en su alcance (pues en el segundo, aparte de probar la inexistencia de obstáculos legales a la celebración - como en el previo al matrimonio - ha de acreditarse también este último hecho y su completo respeto a la forma legal establecida: art. 257 RRC), de acuerdo con la doctrina de la DGRN. Para DíEZ DEL CORRAL RIVAS, J., «Comentarios a los artículos 255 ...», cit., p. 503, este último extremo es el más difícil de justificar cuando se trata de probar matrimonios celebrados en el extranjero ante la autoridad local porque, si no hay título documental oportuno, tampoco hay testigos que puedan declarar, generalmente después de muchos años, cómo se ha celebrado el matrimonio.

${ }^{74}$ Así lo entiende un acreditado sector de la doctrina. Entre otros, LuCES GIL, F., op. cit., p. 277, MARín LóPEZ, M. J., «Comentario al artículo 61 del Código Civil» en Comentarios al Código Civil, Bercovitz Rodríguez-Cano, R. (coord.), Navarra, 2009, pp. 185-186 o Marchal Escalona, N., op. cit., p. 7.

75 Así lo afirma Ramírez Navalón, R.M, op. cit., p. 913, poniendo como ejemplo de lo dicho el Registro de Valencia o LuCES GIL, F., op. cit., p. 231, quien mantiene que para la inscripción de los matrimonios islámicos «normalmente será necesaria la instrucción de un expediente registral previo a la inscripción». Son muchos los autores que se inclinan por la necesidad de acudir directamente a la vía prevista en el artículo $257 \mathrm{RRC}$, y no a la del artículo $256.2 \mathrm{RRC}$, cuando se promueve la inscripción de un matrimonio islámico celebrado sin expediente matrimonial previo. Por todos, vid., Rodríguez Chacón, R., op . cit., p. 719 o Martínez Rubio, A., op. cit., p. 283. No obstante, no creemos que en la práctica se distingan con claridad los trámites seguidos ex artículo 256 RRC y la tramitación del expediente del artículo 257 RRC. Es decir, numerosas resoluciones de la DGRN hacen referencia a la práctica de «audiencias reservadas» y a la «presentación de documentos» en la comprobación que a posteriori lleva a cabo el juez encargado sobre la concurrencia de los requisitos de capacidad. Por todas, la Resolución 19-5-2009, cit. Por tanto, teniendo en cuenta que la audiencia reservada es el trámite esencial del expediente matrimonial a través del cual debe determinarse (por la entrevista con los interesa- 
Por ello, quizá hubiera sido más conveniente que la DGRN impusiera la necesidad de tramitar expediente posterior para lograr la inscripción de un matrimonio islámico sin expediente previo, en lugar de remitir exclusivamente a los medios del artículo $256 \mathrm{RRC}$. Sobre todo, teniendo en cuenta que las particularidades de la religión islámica - existencia de pluralidad de ritos matrimoniales, poligamia, repudio, etc. - complican la comprobación por el encargado de la concurrencia de los requisitos de validez civiles. Complejidad que aumenta cuando dicha comprobación debe hacerse una vez celebrado el matrimonio y en base a documentos claramente insuficientes -y en ocasiones incompletos - para calificar la capacidad matrimonial de los contrayentes. Y es que, cuando la comprobación se hace a posteriori y se detecta alguna irregularidad, surge el problema de determinar en qué situación queda un matrimonio ya celebrado que no ha podido ser inscrito, bien porque a juicio del encargado no se cumplían los requisitos de fondo o forma, bien porque los mismos no han podido acreditarse a través del título presentado ${ }^{76}$, asunto que por sus implicaciones prácticas trataremos con detalle a continuación.

\section{Problemática de los matrimonios cuya inscripción se ha denegado: el caso de la sentencia del Tribunal Constitucional 194/2014, de 1 de diciembre}

La situación descrita no es infrecuente cuando se trata de matrimonios islámicos celebrados sin expediente previo que pretenden su acceso al Registro con la certificación del matrimonio emitida por el repre-

dos y el examen de los documentos que estos aporten), si existen o no obstáculos legales para la autorización de la celebración del matrimonio, ¿qué diferencia habría con la tramitación del expediente del artículo 257 RRC? El análisis de las Resoluciones del Centro Directivo, nos lleva a cuestionarnos si, aunque en teoría las declaraciones complementarias de las que habla el artículo 256 RRC no son un expediente en sentido estricto, en la práctica sí vendrían a serlo. Puede que esta sea la impresión de DURÁN RIVACOBA, R., «El expediente...», cit., nota 65, p. 3144, y por ello afirme que «no se comprende cómo se podrán disipar las dudas acerca de la realidad y legalidad del matrimonio con el fin de proceder a la inscripción sin acudir a un expediente, máxime cuando el artículo 256 RRC habla de "declaraciones complementarias oportunas"».

${ }^{76}$ Esto ocurre frecuentemente respecto de matrimonios, bien celebrados en España, bien en el extranjero, transcurridos bastantes años desde el pretendido enlace. Vid., RRDGRN citadas por DíEz DEL CORRAL RIVAS, J., «Comentario a los artículos 69 y siguientes...», cit., nota 3, p. 760. 
sentante de su Comunidad ${ }^{77}$. Esto es precisamente lo que ocurre en el caso resuelto por la reciente sentencia del Tribunal Constitucional 194/2014, de 1 de diciembre ${ }^{78}$, donde se observa la problemática que plantea la denegación de la inscripción registral, en concreto, por lo que se refiere a la pensión de viudedad.

Se trataba de un matrimonio celebrado por el rito islámico sin haber tramitado expediente previo y sin haber procedido a inscribirlo en el Registro. Fallecida la esposa años después, se promueve la inscripción fuera de plazo y la misma es denegada, denegación que a su vez provoca que la Administración no reconozca el derecho a la pensión de viudedad del esposo y que en definitiva es la razón que lleva al interesado a recurrir a la vía judicial solicitando la reparación del perjuicio sufrido. El motivo por el que se deniega la inscripción es que el solicitante no consigue acreditar ante los encargados de los respectivos Registros Civiles que en el momento del matrimonio concurrieron todos los requisitos de validez. Y ello porque el documento acreditativo del enlace era incompleto (puesto que únicamente hacía mención a la celebración del acto, la fecha y el lugar del mismo) y con él no quedaron despejadas todas las dudas acerca de la realidad y legalidad del hecho ${ }^{79}$.

${ }^{77}$ Pueden verse, entre otras, las Resoluciones de la DGRN 19-5-2009 (JUR 2010\301896) y 30-9-2010 (JUR 2011\314744).

78 RTC 2014\194.

79 Tal como recogen los Antecedentes de Hecho, en el certificado matrimonial únicamente se hacía constar que «el matrimonio se celebró el día 15 de julio de 1999 con el consentimiento de ambas partes». Por ello, el TC estima que, a pesar de que ese matrimonio podía haberse inscrito en virtud de la regla excepcional aplicable a los matrimonios islámicos, «el representante de la Comunidad Islámica que acreditó su celebración, sin embargo, no hizo constar expresamente las circunstancias exigidas por la legislación del registro civil». Respecto a esto nos planteamos también hasta qué punto es reprochable al recurrente el hecho de que en el certificado matrimonial no se contengan todos los requisitos exigidos por la legislación civil. Si los certificados eclesiásticos son incompletos, a pesar de que la ley les obliga a que hagan constar todas las circunstancias exigidas por la legislación del Registro Civil (ex arts. 7.3 Ley 26/1992 y 7.5 Leyes 24 y 25/1992) e incluso hay un modelo oficial aprobado por la Orden del Ministerio de Justicia de 21 de enero 1993 (BOE 3 de febrero de 1993, n. ${ }^{\circ}$ 29, [p. 2931]) ¿quién debería responsabilizarse de tales defectos? ¿el particular que confía en los órganos de su comunidad y que por un error de estos tiene que soportar consecuencias tan gravosas como la denegación de la inscripción y en consecuencia la de una pensión de viudedad? ¿o la propia Confesión? Señala MARTínez Rubio, A., op . cit., p. 279, que tal como ha podido comprobar en el Registro Civil único de Madrid, en la práctica registral el certificado de matrimonio islámico no se corresponde con el que se encuentra en la Orden citada. Debe tenerse en cuenta también que la Circular de la DGRN de 15-21980, sobre inscripción en el Registro Civil de los matrimonios canónicos, establece 
Como ya se dijo, en casos como el presente se debe comprobar con especial cuidado la capacidad de los contrayentes. De ahí que, cuando el certificado eclesiástico no contenga todos los datos requeridos, sea precisa la labor del encargado acordando la práctica de las declaraciones complementarias, o incluso la instrucción de expediente, antes de denegar la inscripción ${ }^{80}$.

En la sentencia comentada, los antecedentes de hecho no inciden lo suficiente en el contenido del auto denegatorio de la inscripción y es difícil saber a ciencia cierta si el encargado fue lo suficientemente diligente en este sentido. Del relato fáctico de la sentencia solo se extrae que la denegación de la inscripción matrimonial se debió exclusivamente a la falta del certificado de capacidad previo, motivo que a nuestro modo de ver no sería suficiente desde el momento en que, como ya expusimos, el misma no es preceptivo ni para la válida constitución del enlace, ni para su inscripción, sin perjuicio de que sea altamente recomendable contar con él ${ }^{81}$.

Llegados a este punto cabría plantearse la cuestión fundamental que a nuestro modo de ver habría que dilucidar en el caso analizado: ¿en

unas instrucciones sobre esta cuestión. Entre ellas, dispone que «los encargados de los Registros civiles procurarán obtener la colaboración de los párrocos de sus respectivos territorios a fin de que las certificaciones eclesiásticas contengan las circunstancias requeridas para la inscripción, especialmente los datos registrales del nacimiento de los esposos». Debería preverse lo mismo para el resto de Confesiones. Por otro lado, y aunque en la sentencia comentada no se menciona nada al respecto, la DGRN ha considerado en algunas de sus Resoluciones que el certificado expedido a posteriori por los centros religiosos sobre celebración en sus dependencias del matrimonio entre los solicitantes, «no es título válido para la inscripción porque no es el acta de celebración y en muchos casos ni siquiera acredita la pertenencia del Imam autorizante a una de las Comunidades Islámicas enunciadas en el artículo 1.1 del Acuerdo de Cooperación». Vid., por todas, la RDGRN de 9-6-2011 (LA LEY 29654312011). Creemos que esto es lo que ocurre en la sentencia ahora analizada, aunque no se diga expresamente.

${ }^{80}$ LUCES GIL, F., op. cit., p. 232, señala que cuando la certificación matrimonial ofrezca alguna duda de la realidad o legalidad del matrimonio, habrán de realizarse las comprobaciones necesarias antes de proceder a la inscripción (arts. 256 y 257 RRC) - parece que con carácter obligatorio e imperativo-.

${ }^{81}$ En los Antecedentes de Hecho se dice que el encargado del Registro de Santiago ante el que se promovió la inscripción denegó la práctica del asiento alegando que, puesto que la ceremonia se había celebrado sin que existiera el preceptivo certificado de capacidad matrimonial, la normativa aplicable no permitía inscribir como matrimonio el casamiento del solicitante por no cumplir los requisitos legales que determinan la inscripción. Que el motivo de la denegación de la inscripción registral del matrimonio es la inexistencia de certificación de capacidad se reitera en numerosas ocasiones a lo largo de la sentencia: vid., Antecedente de Hecho $2 .^{\circ}$, letra c) y párrafo final, Antecedente de Hecho $8 .^{\circ}$ y penúltimo párrafo del Fundamento de Derecho $2{ }^{\circ}$. 
qué situación jurídica quedaría el matrimonio celebrado por el rito islámico sin expediente matrimonial previo y cuya inscripción en el Registro ha sido denegada?

Con carácter general, el matrimonio cuya inscripción se ha denegado carece de una situación clara en nuestro ordenamiento y las opiniones doctrinales respecto al mismo son dispares ${ }^{82}$. A nuestro juicio, no puede concluirse que la denegación de la inscripción implique necesariamente la nulidad o ilegitimidad del enlace ${ }^{83}$. Pero es evidente que para reclamar los derechos que derivan del estado civil de casado, deberá acreditarse previamente la condición de cónyuge legítimo. Si la vía principal para hacerlo no ha concluido favorablemente, esto es, con la práctica del asiento, ¿quiere ello decir que los contrayentes no podrán hacer valer los derechos derivados de su condición de casados de ninguna manera? Y por lo que aquí interesa ¿quiere ello decir que el cónyuge viudo no podrá cobrar la pensión de viudedad que le corresponda según la ley? ¿cómo deberán de actuar los interesados en estos casos?

Hay que tener en cuenta que en nuestro sistema legal las certificaciones del Registro Civil constituyen prueba plena y privilegiada de los hechos inscritos ${ }^{84}$. Consecuentemente, la no inscripción o su denegación, con independencia de cuál sea su causa, excluye al matrimonio de este beneficioso régimen posibilitando la negativa a la actuación de efectos matrimoniales con fundamento en la falta de prueba del mis$\mathrm{mo}^{85}$. Esto vino a ser lo acaecido en el caso resuelto por la STC 194/2014

${ }^{82}$ Sobre las diferentes posturas doctrinales puede verse con más detalle, BARBER CÁRCAMO, R., «La incidencia del principio de igualdad ante la ley sobre el matrimonio no inscrito. Consideraciones en torno a la STC 199/2004, de 15 de noviembre (RTC 2004, 199)», Repertorio Aranzadi del Tribunal Constitucional, n. ${ }^{\circ}$ 4/2005 (Estudio), http://www.westlaw.es (BIB 20051906).

${ }^{83}$ En mismo sentido, por todos, Díez del Corral Rivas, J., «Comentarios a los artículos 69 y siguientes ...», op. cit., p. 760, GARCÍA CANTERO, G., op. cit., p. 164 y De Pablo Contreras, P., op. cit., p. 478.

${ }^{84}$ Así lo dispone el artículo 2 LRC y el artículo 17 nueva ley RC. Tales certificaciones son el título de legitimación principal en nuestro ordenamiento, siendo la posesión de estado el título de legitimación de segundo grado, solo válido en defecto del anterior. Así lo señala Bercovitz Rodríguez-Cano, R., Manual de Derecho Civil. Derecho privado y Derecho de la persona, Madrid, 2011, p. 107.

${ }^{85}$ En caso de denegación de la inscripción con un matiz añadido, puesto que queda justificada en mayor medida una prevención del sistema a la atribución de efectos propios del matrimonio válido. En este sentido, BARBER CÁRCAMO, R., op. cit., p. 12. No obstante, aun no siendo inscribible por no reunir los requisitos civiles de validez o no haber sido estos acreditados debidamente, el matrimonio puede acceder al Registro mediante anotación (art. 271 RRC) cuando, como dispone la DGRN, haya constancia de las circunstancias esenciales sobre el lugar y fecha del matrimonio. La misma tiene 
donde los órganos administrativos no concedieron la pensión en base a que la inscripción registral del matrimonio había sido denegada. Así, señala la Dirección General de Costes de Personal que, al haberse denegado la inscripción, el recurrente no ostentó la condición de «cónyuge legítimo»; y el Tribunal Económico-Administrativo Central supedita la concesión de la pensión a la inscripción registra ${ }^{86} \mathrm{e}$ insta al interesado a volver a solicitarla en caso de conseguir inscribirlo ${ }^{87}$.

Habría que matizar estos argumentos porque, de forma contraria a lo que parece desprenderse de ellos, la inscripción no es constitutiva del vínculo matrimonial ni de la misma depende su legitimidad, ni en consecuencia el derecho a la pensión de viudedad del cónyuge supérstite ${ }^{88}$. Ahora bien, sin perjuicio de lo afirmado, el Tribunal Supremo ha considerado que a dicha solución no es contradictoria con el hecho de que en otros supuestos en los que pueda existir duda acerca de la constitución

carácter meramente provisional e informativo (art. 38 LRC 1957 y art. 40 LRC 2011), pudiendo procederse a la inscripción cuando haya constancia de que se cumplen las condiciones de validez.

${ }^{86}$ En contra de lo que mantiene la doctrina mayoritaria y la jurisprudencia que no consideran imprescindible la inscripción para lucrar pensión de viudedad. Por todos, RiVAS VALLEJO, P., «Efectos del matrimonio no inscrito en el ámbito de las pensiones de viudedad», Aranzadi Social, paraf. 10 (Presentación), http://www.westlaw.es (BIB 2001\605), p. 2; BARBER CÁRCAMo, R., op. cit., p. 7; Arias DomíngUEZ, A., op. cit., p. 5.

${ }^{87}$ Señala DíAz MARTínEZ, A., «Comentario al artículo 61 CC», en Comentarios al Código Civil, vol. 1, dir. R. Bercovitz Rodríguez-Cano, Valencia, 2013, p. 746, que en las relaciones de los particulares con la Administración ha de tenerse en consideración que el requerimiento de esta para que aquellos presenten certificación actualizada de su matrimonio no ha de interpretarse, necesariamente, como intención de no dar por existente el vínculo matrimonial si no está inscrito en el Registro, obviando lo dispuesto en el artículo $61 \mathrm{CC}$, sino de asegurar la permanencia de este, sin que haya sido declarado nulo o se haya decretado el divorcio, o de conocer si el matrimonio se ha separado.

${ }^{88}$ En este sentido se pronuncia la Audiencia Nacional en la sentencia objeto del recurso de amparo que estamos comentando (vid.,SAN 12-11-2012 [JUR2012l359699], FD $6^{\circ} .^{\circ}$. También el Ministerio Fiscal aclara en su demanda que «la falta de inscripción en el Registro Civil no fue la causa de denegación del derecho pretendido por el recurrente, sino la duda sobre su existencia y validez». Tanto el TC como el TS han mantenido esta postura en sus sentencias de 15-11-2004 (RTC 2004\199) y 15-12-2004 (RJ 2005 2170), respectivamente. En mismo sentido, la DGRN. Vid., por todas, la Resolución de 23-5-1994 (RJ 1994\5076). Esto no significa que la inscripción no sea obligatoria. De hecho, esta obligación viene impuesta incluso por normas internacionales. Así, el artículo 4 de la Convención sobre el consentimiento para el matrimonio, la edad mínima para contraer matrimonio y el registro de los matrimonios, abierta a la firma y ratificación por la Asamblea de la ONU en 1962, establece que «todo matrimonio deberá ser inscrito por la autoridad competente en un registro oficial destinado al efecto». 
del vínculo o de su validez, se requiera la efectiva inscripción en el Registro Civil para que pueda producir efectos frente al Instituto Nacional de la Seguridad Social, pues en tales casos la inscripción no juega como condicionante de la existencia del vínculo sino como prueba de su real existencia. Y en base a esto afirma que «si bien la inscripción en el Registro no tiene efectos constitutivos, sí puede tener efectos "prestacionales" frente al INSS» ${ }^{89}$.

No obstante, esto no impide que, en defecto de inscripción, el matrimonio pueda ser probado por otras vías. Como se desprende del artículo 2 LRC 1957 (y art. 17 LRC 2011), la inscripción en el Registro solo es prueba tasada del matrimonio si se ha practicado, pero a falta de ella, y tanto en el tráfico como en el proceso, puede emplearse cualquier otro medio de prueba siempre que al propio tiempo, quien trate de demostrar la existencia del matrimonio, justifique haber instado la inscripción omitida $^{90}$. Ante esta circunstancia, cualquier operador jurídico y no solo el juez podrá valorar libremente la prueba presentada, pudiendo llegar a entender demostrada la existencia del matrimonio o no, con las consecuencias correspondientes.

La doctrina coincide en que la situación de inseguridad en que queda un matrimonio ya celebrado cuya inscripción se ha denegado, «podría salvarse recurriendo a los Tribunales civiles, instando bien la declaración de la validez del matrimonio que ocasione la correspondiente inscripción, bien la nulidad del mismo. La primera será la pretensión lógica de quienes defiendan la validez matrimonial; la segunda habrá de instarse por el Ministerio Fiscal y constituye el lógico desenvolvimiento de la negativa a la inscripción por parte del encargado del Registro Civil» ${ }^{91}$. El atractivo de la acción declarativa del matrimonio «residiría

${ }^{89}$ FD 2. ${ }^{\circ}$ de la STS 15-12-2004, cit., en unificación de doctrina.

90 Vid., STS 29-5-1984 (RJ 198412805). También lo declara así la DGRN en sus Resoluciones de 9-9-1998 (LA LEY 10241\1999), 21-1-1998 (LA LEY 8518\1998) o 7-4-1997. Entre los posibles medios de prueba ocupará un lugar relevante el acta de la celebración o la certificación eclesiástica. En el caso resuelto por la sentencia aquí comentada, no es solo que la inscripción se hubiese instado - condición que permitiría presentar pruebas ajenas al Registro para acreditar el matrimonio-, sino que la misma había sido ya denegada al tiempo de solicitar la pensión de viudedad.

91 Barber Cárcamo, R., op. cit., p. 12. En mismo sentido, García Cantero, G., op. cit., p. 164 o Díez del CoRRAl Rivas, J., «Comentarios a los artículos 255 y siguientes...», cit., pp. 504-505, De PABlo Contreras, P., op. cit., p. 478. Para este último, nada impedirá a los interesados acudir a los Tribunales para que declaren la eficacia civil del matrimonio, no solo - una vez agotada la vía gubernativa ante la DGRN - cuando se deniegue la práctica del asiento. En el Derecho inglés, también es posible acudir a los Tribunales en virtud del artículo 55 de la Family Law Act 1986, 
en soslayar el peligro de que indirectamente los Organismos registrales se atribuyan a través de la calificación funciones que en puridad competen exclusivamente a los Tribunales. [...] Por más que se denegara la inscripción, movidos los registradores por ese especial celo que deben extremar cuando está comprometido el orden público y se intensifica el peligro de la bigamia, siempre cabría probar ante el juez, de acuerdo con esto, que el matrimonio se constituyó válidamente» ${ }^{92}$.

Probada por medios extrarregistrales la existencia y validez del matrimonio, se procederá a su inscripción, momento en que desplegará eficacia plena ${ }^{93}$. Pero nada de esto hizo el recurrente en amparo. Desde el inicio del procedimiento se limitó a mantener la validez de su matrimonio y a considerar prueba suficiente del mismo el certificado de celebración expedido por el representante de la Comunidad Islámica de Galicia ${ }^{94}$. Sostuvo en todo momento que la Administración había admitido la existencia y validez de su matrimonio ${ }^{95}$ y que, por ello, teniendo

para obtener una declaración de validez del matrimonio que aclare el estatus de los contrayentes. Vid., Herring, J., Family Law, Oxford, 2009, p. 45.

${ }^{92}$ Son palabras de CABEZuelo ARENAS, A.L., «Ilegitimidad de matrimonio contraído por el rito islámico: Denegación de inscripción en el Registro Civil y de la pensión de viudedad», Revista Aranzadi Doctrinal n. ${ }^{\circ}$ 5/2015, parte Comentario (BIB 2015\1323), p. 4, siguiendo en este punto a RAMOS CHAPARRO.

${ }_{93}$ La doctrina mayoritaria considera que el «pleno reconocimiento» de los efectos civiles no es sino la posibilidad de oponer dichos efectos a los terceros de buena fe, cosa que solo podrá hacerse tras la inscripción del matrimonio en el Registro. En este sentido, por todos, Albaladejo García, M., Curso de Derecho Civil, IV, Derecho de Familia, Madrid, 2006, p. 68 o MARín LÓPEZ, M. J., op. cit., p. 182. Sobre las distintas posturas acerca de esta expresión vid., BARBER CÁRCAMo, R., op. cit., pp. 7 y ss.

94 Aun a pesar de que la denegación de la inscripción registral llevara al recurrente a solicitar la pensión de viudedad como pareja de hecho, en todo momento se declaró como viudo (vid., AH 2. ${ }^{\circ}$, letra b) y adjuntó el certificado de matrimonio islámico. Debido a que presentó la solicitud en calidad de «pareja de hecho del causante» la Dirección General de Costes de Personal y Pensiones Públicas le denegó la prestación porque no cumplía los requisitos exigidos por la legislación al efecto para su reconocimiento, entre ellos, el plazo improrrogable dentro del cual tenía que haber presentado su solicitud y que sobrepasó ampliamente.

${ }_{95} \mathrm{El}$ hecho de que la Administración reconociera la existencia del matrimonio (pues no debe olvidarse que el actor contaba con un certificado matrimonial), no significa que estuviera admitiendo su legitimidad o validez. Es decir, el hecho de que el recurrente hubiera contraído matrimonio (no vivía en pareja de hecho o more uxorio), no implicaba per se la validez del mismo. Y es que, como matiza con acierto el $\mathrm{TC}$, «no cualquier matrimonio contraído bajo el rito islámico tiene validez en España, sino solo aquellos que cumplan las exigencias que fueron acordadas por el Estado español y la Comunidad islámica, reguladas en la citada Ley 26/1992, de 10 de diciembre (FD 5..$\left.^{\circ}\right)$. 
en cuenta que los efectos del mismo se producen desde su celebración (ex arts. 61 CC, 70 LRC y 7 Ley 26/1992), la falta de inscripción no debía impedir el reconocimiento de la pensión en tanto que la misma solo se requiere a efectos de publicidad con el fin de poder oponer el matrimonio a terceros de buena fe.

Pues bien, la hipótesis de la que parten los preceptos citados cuando disponen que el matrimonio despliega efectos desde su celebración, es la de un matrimonio válidamente celebrado en cuanto a su forma y fondo. Ahora bien, hasta que dicho extremo no quede acreditado es evidente que los efectos del matrimonio no se pueden hacer valer frente al Estado. Es decir, el Estado ha de comprobar no solo que el matrimonio existe sino que es legítimo, esto es, que respeta los requisitos civiles. Y en el caso ahora comentado es precisamente la legitimidad del matrimonio lo que se discute, extremo que no probó el interesado ni en la vía administrativa, ni en la judicial.

La estrategia seguida por el recurrente no fue la adecuada porque el problema de fondo en este asunto era principalmente de carácter probatorio y no de falta de inscripción matrimonial. Por ello, en vez de plantear su demanda por la vía de la vulneración del principio de igualdad del artículo $14 \mathrm{CE}$ respecto a otros matrimonios a los que, por diversos motivos, se les había reconocido la pensión de viudedad, creemos que debería haber iniciado un procedimiento judicial con el fin de que los tribunales civiles reconocieran la validez de su matrimonio, presentando para ello, tal y como permite la ley, cualquier medio de prueba admitido en Derecho.

$\mathrm{Al}$ no hacerlo así, el TC estima inexistente la vulneración del derecho a la igualdad desde el momento en que ninguno de los términos de comparación aportados para probar la discriminación sufrida guardaba con el enjuiciado la identidad que todo juicio de igualdad requiere ${ }^{96}$. No

${ }^{96}$ Por un lado, cuando el recurrente equipara su situación con la que fue objeto de conocimiento por el TC en su sentencia 199/2004, de 15-11-2004 (RTC 2004\199), parte de una premisa equivocada que hace decaer su argumentación. El matiz diferencial es que en aquel caso, a pesar de la falta de inscripción, se partió en todo momento de la existencia de un «matrimonio válidamente celebrado de acuerdo con nuestro ordenamiento jurídico», mientras en este, a diferencia de lo que alega el recurrente, es precisamente la legitimidad y validez del matrimonio islámico lo que se pone en duda. Tras recordar la especial importancia que se otorga en el artículo 7.1. Ley 26/1992 a la constatación de los requisitos de capacidad para la atribución de efectos civiles, el TC concluye que el matrimonio por el rito islámico contraído por el recurrente carecía de validez y eficacia para el ordenamiento español porque los contrayentes en ningún momento cumplieron (aunque en nuestra opinión debería 
obstante, teniendo en cuenta que el TC concluye que el matrimonio del recurrente carecía de validez civil, cabría plantearse si atendiendo a las circunstancias del caso podrían haberse reconocido al menos los efectos del matrimonio putativo con el fin de posibilitar el acceso a la pensión de viudedad reclamada (tal y como al fin y al cabo sucedió en la sentencia del TEDH alegada por el recurrente). Simplemente dejaremos apuntado que a nuestro juicio sería una hipótesis no descartable desde el momento en que el recurrente actúa de buena fe (reconocida incluso por el Ministerio Fiscal cuando señala que «cabe reconocerle la existencia de buena fe al recurrente en cuanto a considerar su unión con la finada como un matrimonio» - vid., $\mathrm{AH} 8 .^{\circ}-$ ) y existe cierta apariencia matrimonial (mínimo de forma), requisitos que deben concurrir para poder mantener los efectos del matrimonio entre los cónyuges ${ }^{97}$. A esta posibilidad alude tanto la doctrina, como la DGRN en los casos en que no se ha procedido a inscribir el matrimonio o se ha denegado la inscripción ${ }^{98}$.

decir «acreditaron») los requisitos de capacidad exigidos por la ley española, ni con carácter previo, ni con posterioridad a la celebración del matrimonio; por otro lado, el recurrente cita también en apoyo de su pretensión la STEDH, de 8 de diciembre de 2009, Caso Muñoz Díaz c. España. No obstante, el TC considera que tampoco es comparable su situación con la de la viuda de un matrimonio celebrado conforme al rito gitano que vio reconocida la pensión de viudedad exclusivamente por las especiales circunstancias que concurrieron en el caso concreto y no porque se estimase, como algunos quisieron ver, que las uniones celebradas por ritos no reconocidos por Estado gozasen de efectos civiles. Para mayor detalle sobre esta sentencia del TEDH puede verse BERENGUER ALBALADEJO, C., «El principio de igualdad y no discriminación en relación con la pensión de viudedad y el "matrimonio gitano"», $D P y C$, n. $.^{\circ} 24,2010$, pp. 109-162.

${ }^{97}$ A esto habría que añadir que normalmente la jurisdicción social se inclina por reconocer pensiones de viudedad en casos muy discutibles (vid., a modo de ejemplo, el elenco de sentencias analizadas por ARIAS DomínguEZ, A., op. cit., pp. 5-6), otorgando prevalencia a la cobertura prestacional de las partes en detrimento de la consideración técnica sobre el régimen civil del matrimonio y su inscripción. En este sentido también señala Díez MARTínEZ, A., op. cit., p. 833, que con el fin de reconocer el derecho a la pensión de quien contrajo matrimonio con una persona ya casada, no siempre se aplica correctamente el artículo 79 CC y aun no habiendo declaración judicial de nulidad del segundo matrimonio, lo consideran como putativo.

98 Así, según Díez del CorRal Rivas, J., «Comentarios a los artículos 69 y siguientes...», cit., p. 760 , los casos de «matrimonios no inscribibles podrán beneficiarse de los efectos del llamado matrimonio putativo conforme al artículo $79 \mathrm{CC}$. Y según AldDANONDo Salaverría, I., op. cit., p. 396, no puede excluirse la eficacia de un matrimonio islámico nulo en concepto de matrimonio putativo. Por su parte, el Centro Directivo mantiene en su Resolución de 10-7-1996, entre otras, que «El hecho de que este matrimonio no pueda ser inscrito en el Registro Civil por las razones apuntadas (impedimento de ligamen en el caso concreto), no ha de impedir, conforme a los artículos 61 


\section{BREVE EXPOSICIÓN DE LAS MODIFICACIONES LEGISLATIVAS OPERADAS POR LA LEY 15/2015, DE 2 DE JULIO, DE LA JURISDICCIÓN VOLUNTARIA RESPECTO A LA TRAMITACIÓN DEL EXPEDIENTE MATRIMONIAL}

Es muy importante la nueva regulación que del acta o expediente previo a la celebración del matrimonio recoge el Código Civil. Así lo considera el legislador en la Exposición de Motivos de la LJV ${ }^{99}$. La primera novedad la establece el artículo $51 \mathrm{CC}$ y se refiere a la competencia para su tramitación. La reforma implica un apoderamiento al notario y al secretario judicial y un «reapoderamiento» al encargado del Registro Civil - aunque estos ya no vayan a ser jueces - , en detrimento de la atribución exclusiva que estableció el artículo 58.2 LRC en favor del secretario del Ayuntamiento ${ }^{100}$. Como se apunta en la Exposición de Motivos, «[t]odo ello se enmarca igualmente en el proceso de diversificación de los elementos personales ante los que se lleva a efecto la autorización de determinados actos, que permite la concentración de la Administración de Justicia a la labor fundamental que la Constitución les atribuye de juzgar y ejecutar lo juzgado» ${ }^{101}$. Además, teniendo

\footnotetext{
y 79 del Código Civil, que el matrimonio islámico haya de surtir, al menos, los efectos del matrimonio putativo [...] al existir una apariencia objetiva de celebración de matrimonio y demás requisitos mínimos que deben exigirse para la existencia del llamado matrimonio putativo». Vid., también, la Resolución de 23-5-1994, cit.

${ }^{99}$ Ap. XI. Obsérvese que la reforma conlleva que deje de hablarse únicamente de «expediente» matrimonial, para pasar a hacerlo de «acta» o «expediente», en función de quien lo tramite: el notario en el primer caso, el secretario judicial o el encargado del Registro Civil en el segundo.

100 Esto ha conllevado la modificación de la Disposición Adicional 5. a de la LRC con el fin de suprimir la tasa que iban a cobrar los Ayuntamientos por la instrucción y tramitación de los expedientes matrimoniales. Ahora únicamente se establece una tasa por la celebración de los matrimonios en forma civil. Asimismo, se prevé que los notarios cobren el correspondiente arancel por su intervención en la tramitación de las actas matrimoniales previas, arancel que será fijado por el Gobierno tal como dispone la Disposición final 5. ${ }^{a}$ bis de la LRC. En este último punto no se han tenido en cuenta las consideraciones realizadas por el CGPJ acerca de la conveniencia de concretar este arancel en vez de habilitar al Gobierno para su fijación sin establecer ningún tipo de pauta. La recomendación del CGPJ fue que los documentos notariales relacionados con la autorización y celebración del matrimonio se incardinasen en los «Documentos sin cuantía» a los que se refiere el artículo 1.1.h), del Anexo del RD 1426/1989 por el que se aprueba el arancel de los notarios, fijándose su cuantía en unos 30 euros, o que se estableciese un tratamiento similar. Vid., p. 183 del Informe.

${ }^{101}$ A ello aspira con carácter general y prioritario la nueva LJV según su Exposición de Motivos.
} 
en cuenta que la atribución de esta función conlleva la importante tarea de detectar los matrimonios de complacencia o simulados, y con el fin de garantizar que dicho control se lleve a cabo sin interferencias de las partes, se priva a los futuros contrayentes de la posibilidad de elegir notario para la tramitación del acta, fijando que será competente aquel que tenga su sede en el lugar del domicilio de cualquiera de ellos ${ }^{102}$.

Nos parece acertado que se haya suprimido la competencia de los secretarios de los Ayuntamientos para desempeñar esta compleja tarea en la medida en que excede completamente de sus funciones y carecen de formación y organización para llevarla a cabo ${ }^{103}$.

Por otro lado, las reformas en la regulación del expediente matrimonial afectan tanto a los matrimonios en forma civil como religiosa (salvo a los canónicos) porque para su tramitación se aplican las mismas normas en ambos casos ${ }^{104}$. Por ello, se han tenido que realizar los correspondientes ajustes en las Leyes 24, 25 y 26 de 1992 con el fin, por un lado, de prever las novedades mencionadas, y por otro lado, de introducir una serie de modificaciones respecto al título necesario para la inscripción y a la forma de llevarla a cabo. Sobre este último extremo se establece ahora que, una vez celebrado el matrimonio, el ministro de culto oficiante o el representante de la Comunidad Islámica en que se hubiera contraído aquel, extenderá «certificación expresiva de la celebración del mismo, con los requisitos necesarios para su inscripción y las menciones de identidad de los testigos y de las circunstancias del acta o expediente previo que necesariamente incluirán el nombre y apellidos del secretario judicial, notario, encargado del Registro Civil o

102 Vid., el artículo 51.1 CC y el artículo 51.1 Ley del Notariado.

${ }^{103} \mathrm{La}$ atribución a tales funcionarios de la competencia para tramitar estos expedientes no ha estado exenta de críticas. SERnA MERoÑo, E., «Comentario al artículo 58 LRC», en Comentarios a la Ley del Registro Civil, dir. J.A. Cobacho Gómez/A. Leciñera Ibarra, Navarra, 2012, pp. 857 y 863, pone de relieve la falta de medios humanos y técnicos de las alcaldías, sobre todo de municipios pequeños, para asumir con solvencia la llevanza de los expedientes matrimoniales y la falta de experiencia de estas personas para desempeñar una labor que exige un conocimiento profundo de las normas del CC. Sobre la falta de preparación de estos funcionarios también se pronuncia Salom Herrero, F., «Los nuevos responsables de la tramitación de los matrimonios civiles», El Consultor de los Ayuntamientos y de los Juzgados, n. ${ }^{\circ} 11$, Sección Actualidad, Quincena del 15 al 29 de junio. 2014, Ref. 1199/2014,p. 1199, tomo 1 (LA LEY $3385 \backslash 2014)$.

104 Hasta el momento eran los artículos 238 y ss. RRC los que establecían la competencia, tramitación y contenido del mismo. A partir del 30 de junio de 2017 será la propia LRC la que regulará estas cuestiones en el artículo 58, lo que ha dado lugar a un precepto extenso y con un contenido un tanto «reglamentista». 
funcionario diplomático o consular que la hubiera extendido, la fecha y número de protocolo en su caso». Esta certificación se remitirá por medios electrónicos, en la forma que reglamentariamente se determine, junto con la «certificación acreditativa de la condición de ministro de culto o de la capacidad del representante de la Comunidad Islámica para celebrar matrimonios», dentro del plazo de cinco días ${ }^{105}$ al encargado del Registro Civil competente para su inscripción. Igualmente extenderá en las dos copias del acta o resolución previa de capacidad matrimonial diligencia expresiva de la celebración del matrimonio entregando una a los contrayentes y conservará la otra como acta de la celebración en el archivo del oficiante o de la entidad religiosa a la que representa como ministro de culto ${ }^{106}$. Por tanto, para proceder a la inscripción se exige el envío telemático de dos certificados: el de celebración del matrimonio en el que, entre otras cosas, deberá constar que los contrayentes gozan de capacidad matrimonial, y el que acredite la condición de ministro de culto del celebrante.

El hecho de que se haya establecido una redacción casi idéntica en los tres Acuerdos (así como en el art. 58.2. ${ }^{\circ}$ bis respecto a las nuevas formas matrimoniales reconocidas) tiene gran relevancia por lo que se refiere a los matrimonios celebrados por el rito islámico porque da a entender, a nuestro juicio, que a estos también se les va a exigir la tramitación del acta o expediente de capacidad matrimonial previamente a la celebración. Aunque no se diga claramente, esto es lo que parece

105 La referencia a este plazo no se contenía en la anterior redacción en la cual se establecía que la certificación diligenciada tendría que remitirse al Registro «acto seguido» a su expedición o «una vez celebrado el matrimonio». Sí se mencionaba este plazo en el artículo 70 LRC e indirectamente en el Protocolo final del Acuerdo con la Santa Sede, pero posteriormente no fue recogido en el artículo $61 \mathrm{CC}$ redactado por la Ley 30/1981, de 7 de julio. Por ello, la DGRN mantuvo, por un lado, que la inscripción fuera de ese plazo no impedía la producción de efectos del matrimonio desde su celebración (cfr. arts. 61 CC y 70 LRC), y por otro, que ninguna norma imponía que pasado ese plazo hubiera que tramitar expediente para la inscripción del matrimonio, bastando, a tenor del artículo $63 \mathrm{CC}$, con la certificación eclesiástica. Así, por todas, RDGRN 24-5-1994 (LA LEY 12319\1994).

${ }^{106}$ Así lo establece la nueva redacción de los apartados 5 y 3 del artículo 7 de las Leyes 24 y 25 , y de la Ley 26 respectivamente. En la regulación hasta ahora vigente se establecía como título de inscripción la certificación de capacidad en la que se extendía diligencia expresiva de la celebración del matrimonio (art. 7.5 Leyes 24 y 25) o la certificación acreditativa de la celebración del matrimonio (art. 7.3 Ley 26). Mientras estas novedades entrarán en vigor cuando lo haga la LJV (esto es, a los 20 días de su publicación en el BOE), no puede decirse lo mismo de las novedades relativas a la competencia para tramitar el acta o expediente previo, cuya entrada en vigor ha sido aplazada hasta el 30 de junio de 2017. 
desprenderse de la redacción anterior, ya que, si la certificación del matrimonio debe contener las menciones de las circunstancias del expediente o acta previa, no cabe duda que esta ha tenido que tramitarse con anterioridad a su celebración. Igualmente, si el oficiante debe extender diligencia expresiva de la celebración del matrimonio en las dos copias del acta o resolución previa de capacidad y entregar una a los contrayentes, debe tenerlas en su poder al momento de la celebración.

Por tanto, la nueva redacción del apartado tercero del artículo 7 Ley 26/1992 parece aportar un poco de claridad a la contradicción inherente al apartado segundo a la que hicimos referencia en su momento y que no ha sido eliminada por el legislador a pesar de que era relativamente sencillo hacerlo. Hubiera bastado con sustituir la expresión «las personas que deseen inscribir el matrimonio», que además induce a confusión por cuanto parece dejar la inscripción a la libre voluntad de los contrayentes, por la expresión «las personas que deseen celebrar el matrimonio».

Ahora bien, a pesar de la modificación operada, el citado precepto sigue sin establecer que el acta o resolución de capacidad matrimonial sea un requisito de validez (o eficacia) del matrimonio islámico, a diferencia de lo establecido en los otros Acuerdos y en el nuevo artículo $60.2{ }^{\circ} \mathrm{CC}$. En la medida en que el artículo 7.1 no ha sufrido modificación alguna, creemos que dicha nulidad no podría predicarse.

Con estos cambios legislativos, la tramitación de expediente (o acta) de capacidad previo se convierte en un requisito que deben cumplir los matrimonios de cualquier confesión religiosa (salvo la católica), lo que supone una importante novedad para los islámicos. No obstante, hubiera sido conveniente equipararlos también respecto a las consecuencias que el incumplimiento de dicho trámite o de la celebración del matrimonio caducado el certificado de capacidad. Si la intención del legislador era unificar criterios, creemos que en este aspecto no lo ha conseguido. Al menos, esa es la impresión que nosotros extraemos de la interpretación de la nueva situación legislativa.

Por otro lado, aunque no es propiamente objeto de este trabajo, no podemos dejar de referirnos siquiera sucintamente a los cambios operados en la forma de celebración civil del matrimonio. Tras una serie de idas y venidas en este punto durante la tramitación de la Ley, se ha acabado estableciendo que las personas competentes para celebrarlo serán: «1.․ El juez de Paz o alcalde del municipio donde se celebre el matrimonio o concejal en quien este delegue. $2 .^{\circ}$ El secretario judicial o notario libremente elegido por ambos contrayentes que sea competente en el lugar de celebración. 3 . $^{\circ}$ El funcionario diplomático o consu- 
lar encargado del Registro Civil en el extranjero» (art. 51.2 ${ }^{\circ} \mathrm{CC}$ ). Por tanto, se amplía considerablemente el listado de personas ante las que puede prestarse consentimiento marital, teniendo en cuenta que la LRC 20/2011 establecía la exclusividad de alcaldes y concejales. Como novedad respecto al proyecto de Ley inicial, se añade finalmente a los secretarios judiciales para este cometido ${ }^{107}$.

Para finalizar, se debe poner de relieve que a través de una enmienda introducida en el Senado y ratificada por el Pleno del Congreso, se ha aplazado la entrada en vigor de algunas de las modificaciones que hemos analizado en este trabajo ${ }^{108}$. En particular, la tramitación de los expedientes matrimoniales que se inicien antes del 30 de junio del 2017 seguirá correspondiendo al encargado del Registro Civil conforme a las disposiciones del Código Civil y de la Ley del Registro Civil de 8 de junio de 1957. Así lo ordena la Disposición transitoria 4. ${ }^{\text {a }}$ para los matrimonios en forma civil ${ }^{109}$ y la 5 . ${ }^{\text {a }}$ para los matrimonios celebrados por las confesiones religiosas evangélicas, judías e islámicas y por las que hayan obtenido el reconocimiento de notorio arraigo en España. Respecto a estos últimos, también se establece la manera de proceder para

107 En el Proyecto de Ley aprobado por el Gobierno se atribuía exclusivamente a notarios y registradores un catálogo de actos que correspondían hasta ahora a los jueces. Pero finalmente se ha considerado más oportuno introducir el concepto de alternatividad, dando la opción al ciudadano en determinados casos de acudir, no solo al notario o al registrador, sino también a los secretarios judiciales, «para evitar situaciones de imposibilidad de ejercicio de un derecho, que hasta ahora era gratuito, por falta de medios». En los casos en que la competencia para tramitar expedientes sea exclusiva de los primeros, se ha previsto que los ciudadanos puedan obtener el derecho de justicia gratuita.

${ }^{108}$ La Disposición final vigésimo primera de la LJV establece que «las modificaciones de los artículos 49, 51, 52, 53, 55, 56, 57, 58, 62, 65 y 73 del Código Civil contenidas en la disposición final primera, así como las modificaciones de los artículos 58,58 bis, disposición final segunda y disposición final quinta bis de la Ley 20/2011, de 22 de julio, del Registro Civil, incluidas en la disposición final cuarta, relativas a la tramitación y celebración del matrimonio civil, que entrarán en vigor el 30 de junio del $2017 »$.

${ }^{109}$ Esta disposición también establece que, resuelto favorablemente el expediente matrimonial por el encargado del Registro Civil, el matrimonio se podrá celebrar, a elección de los contrayentes, ante: $1 .^{\circ}$ El juez encargado del Registro Civil y los jueces de Paz por delegación de aquel; $2 .{ }^{\circ}$ El alcalde del municipio donde se celebre el matrimonio o concejal en quien este delegue; $3 .^{\circ}$ El secretario judicial o notario libremente elegido por ambos contrayentes que sea competente en el lugar de celebración; $4 .^{\circ} \mathrm{El}$ funcionario diplomático o consular encargado del Registro Civil en el extranjero. En consecuencia, los encargados de los Registros seguirán siendo competentes para celebrar los matrimonios cuyos expedientes se hayan iniciado antes del 30 de junio de 2017, pero no para los posteriores a dicha fecha. 
su celebración hasta la entrada en vigor del artículo 58 bis LRC. No nos detendremos en esta disposición puesto que no introduce novedades respecto a lo ya analizado en su momento.

\section{BIBLIOGRAFÍA}

Acuña Guirola, S./Domínguez Bartolomé, R.: Matrimonio religioso y Unión Europea, Granada, 2013.

Albaladejo García, M.: Curso de Derecho Civil, IV, Derecho de Familia, Madrid, 2008.

Alenda Salinas, M.: «El matrimonio religioso en los acuerdos del Estado español, con judíos, protestantes y musulmanes», Revista General de Derecho, n. ${ }^{\circ} 600,1994$, pp. 9189 y ss.

Arias DomíngueZ, A.: «Matrimonio gitano y devengo de pensión de viudedad», Aranzadi Social, paraf. 35/2007 (Presentación), http://www.westlaw.es (BIB 2007\1233).

Barber CÁrCAmo, R.: «La incidencia del principio de igualdad ante la ley sobre el matrimonio no inscrito. Consideraciones en torno a la STC 199/2004, de 15 de noviembre (RTC 2004\199)», Repertorio Aranzadi del Tribunal Constitucional, n. ${ }^{\circ}$ 4/2005 (Estudio), http://www.westlaw.es (BIB 2005\906).

Bercovitz Rodríguez-CAno, R.: Manual de Derecho Civil. Derecho privado y Derecho de la persona, Madrid, 2011.

CABEZUElo Arenas, A.L.: «Ilegitimidad de matrimonio contraído por el rito islámico: Denegación de inscripción en el Registro Civil y de la pensión de viudedad», Revista Aranzadi Doctrinal n. ${ }^{\circ}$ 5/2015, parte Comentario, (BIB 2015/1323).

- «Matrimonio y parejas de hecho. ¿Es necesaria una reforma del sistema matrimonial español? A propósito de una inexistente discriminación por motivos étnicos», $D P y C$, n. $^{\circ} 21,2007$, pp. 9 y ss.

CARRIÓN Olmos, S.: «Sistema matrimonial y Acuerdos con otras confesiones», $A C, \mathrm{n} .^{\circ} 1,1993$, pp. 93 y ss.

CAÑAMARES, S.: «Ley Orgánica de Libertad Religiosa: oportunidad y fundamento de una reforma», en Derecho canónico en tiempos de cambio, Madrid, 2011.

Cebriá García, M.D.: «La inscripción de los matrimonios religiosos no católicos en el Registro Civil», Familia: Revista de ciencias y orientación familiar, n. ${ }^{\circ} 19,1999$, pp. 79 y ss.

Díaz MARTínez, A.: «Comentario al artículo 61 CC», en Comentarios al Código Civil, dir. R. Bercovitz Rodríguez-Cano, Valencia, 2013, pp. 741 y ss.

DíEZ DEL CORRAL RIVAS, J.: «Comentario a los artículos 69 y siguientes de la LRC», en Comentarios al Código Civil y Compilaciones Forales, tomo IV, vol. 3, 1996, pp. 752 y ss. 
- «Comentarios a los artículos 255 y siguientes del RRC», en Comentarios al Código Civil y Compilaciones Forales, tomo IV, vol. 5, 1997, pp. 488 y ss.

Díez-Picazo Giménez, G. (coord.)/Díez-Picazo y Ponce de León, L. (prol.): Derecho de Familia, Madrid, 2012.

DURÁN RIVACOBA, R.: «El expediente civil previo a la celebración del matrimonio en la reforma del Reglamento del Registro Civil», AC, n. ${ }^{\circ} 3,1989$, pp. 3125 y ss.

FÉliX BALLeSTA, M.A.: «Reflexiones sobre el matrimonio gitano y su posible eficacia civil», RJC, vol. 102, n. ${ }^{\circ} 2,2003$, pp. 83 y ss.

Gallego DomíngueZ, I./Galán Soldevilla, L.: «El matrimonio religioso no canónico celebrado en España, aproximación a las Leyes n. ${ }^{\circ}$ 24, 25 y 26 de 10 de noviembre de $1992 », A C$, n. $^{\circ} 1,1993$, pp. 217 y ss.

García Cantero, G.: «Comentario a los artículos 61 a 65 CC», Comentarios al Código Civil y Compilaciones Forales, dir., M. Albaladejo/S. Díaz Alabart, tomo II, Madrid, 1982, pp. 143 y ss.

GARCÍA VARELA, R.: «La inscripción en el Registro Civil del matrimonio celebrado en forma religiosa», en Homenaje a Don Antonio Hernández Gil, coord. L. Martínez-Calcerrada y Gómez, vol. 3, 2001, pp. 2449-2464.

Herring, J.: Family Law, Oxford, 2009.

LÓPEZ AlarCón, M.: «El certificado de capacidad matrimonial», ADEE, n. ${ }^{\circ} 8$, 1992 , pp. 177 y ss.

Luces Gil, F.: Derecho del Registro Civil, Barcelona, 2002.

Marchal Escalona, N.: «Matrimonio religioso y la Instrucción de 10 de febrero de 1993 de la Dirección General de los Registros y del Notariado», La Ley: Revista jurídica española de doctrina, jurisprudencia y bibliografía, n. ${ }^{\circ} 6,1996$, pp. 1589 y ss.

Marín López, M. J.: «Comentario al artículo 61 del Código Civil» en Comentarios al Código Civil, Bercovitz Rodríguez-CANO, R. (coord.), Navarra, 2009, pp. 181 y ss.

Martinell, J.M./Areces PiÑol, M.T.: «En torno a la incidencia civil de los matrimonios confesionales», en Estudios en Homenaje al profesor Martínez Valls, vol. II, Alicante, 2000, pp. 911 y ss.

Martínez Rubio, A.: «La inscripción del matrimonio islámico en el Registro Civil», $A D E E$, n. ${ }^{\circ} 19,2003$, pp. 263 y ss.

Musoles Cubedo, M.C.: «El matrimonio contraído según el rito gitano, ¿unión de hecho o forma de celebración con eficacia civil?», en Derecho de Familia y libertad de conciencia en los países de la Unión Europea y el Derecho comparado. Actas del IX Congreso Internacional de Derecho Eclesiástico del Estado, San Sebastián, 1 al 3 de junio de 2000, Bilbao, 2001, pp. 649 y ss.

NAVARRo-VALLS, R.: La eficacia civil del matrimonio de las minorías religiosas en el Derecho español, 1993.

- El matrimonio religioso ante el Derecho español, Madrid, 1984. 
PaZ Agueras, J.M.: «El matrimonio en forma religiosa en los acuerdos de cooperación del Estado con las confesiones no católicas», Boletín de Información del Ministerio de Justicia, n. ${ }^{\circ}$ 1661, 1993.

POLO SABAU, J.R.: «La función de la forma de celebración del matrimonio y el principio de igualdad: algunas observaciones a la luz del proyecto de ley de la jurisdicción voluntaria», Revista de Derecho Civil, vol. II, n. 1 (enero-marzo, 2015), Estudios, pp. 25 y ss.

Probert, R.: Family Law in England and Wales, Países Bajos, 2011.

RAMÍREZ NAVALÓN, R.M.: «Los matrimonios religiosos acatólicos: relevancia del expediente previo de capacidad e inscripción en el Registro Civil», en Estudios jurídicos en homenaje al profesor Enrique Lalaguna Domínguez, coord., J. Alventosa del Río/R.M., Moliner Navarro, vol. 2, 2008, pp. 897 y ss.

Reina, V. (coord.)/FÉlix Ballesta, M.A. (coord.): Acuerdos del Estado Español con Confesiones Religiosas Minoritarias, Madrid, 1996.

SERnA Meroño, E.: «Comentario al artículo 58 LRC», en Comentarios a la Ley del Registro Civil, dir. J.A. Cobacho Gómez/A. Leciñera Ibarra, Navarra, 2012, pp. 855 y ss.

YzQuierdo Tolsada, M. (dir.)/Cuenca CAsas, M. (dir.): Tratado de Derecho de Familia, vol. 1, Navarra, 2011. 